Check for updates

Cite this: RSC Adv., 2017, 7, 39686

Received 28th April 2017

Accepted 8th August 2017

DOI: $10.1039 / c 7 r a 04798 c$

rsc.li/rsc-advances

\section{A DFT analysis on the radical scavenging activity of oxygenated terpenoids present in the extract of the buds of Cleistocalyx operculatus $\uparrow$}

Thi Chinh Ngo, ${ }^{a}$ Duy Quang Dao, (D) *a Minh Thong Nguyen ${ }^{\mathrm{b}}$ and Pham Cam Nam ${ }^{\mathrm{c}}$

The antioxidant capacity of twenty-one oxygenated monoterpene and oxygenated desquiterpene compounds in the extract from Cleistocalyx operculatus has been computationally evaluated. Calculated by (RO)B3LYP/6-311++G(2df,2p)//B3LYP/6-311G(d,p) model chemistries, the thermochemical parameters, namely BDE, IE, PDE, PA and ETE in the gas phase, water and ethanol were determined. In addition, quantum descriptors, which allow the evaluation of the reactivity and stability of the resulting radicals like chemical potential $(\mu)$, hardness $(\eta)$ and global electrophilicity $(\omega)$ were also computed. Potential energy surfaces of the reactions between $\mathrm{CH}_{3} \mathrm{OO}$ and $\mathrm{HO}^{\circ}$ radicals with falcarinol and $\alpha$-vetivone, two typical and potential antioxidant molecules, were established to give more insight into the antioxidant mechanism. The obtained results underline falcarinol as the most effective antioxidant with the lowest BDE of $66.5 \mathrm{kcal} \mathrm{mol}^{-1}$ and PA of $341.3 \mathrm{kcal} \mathrm{mol}^{-1}$ in the gas phase. Among the reactions on falcarinol, the $\mathrm{H}$-abstraction at $\mathrm{C} 3-\mathrm{H}$ position by both $\mathrm{CH}_{3} \mathrm{OO}$ and $\mathrm{HO}$ radicals are favorable with the energy barriers of -18.7 and $-54.7 \mathrm{kcal} \mathrm{mol}^{-1}$, respectively. Moreover, NBO analysis helps to clarify the mechanism of antioxidant action which shows that the third lone pair of electrons on O1-atom of $\mathrm{CH}_{3} \mathrm{OO}$ radical is donated to an unoccupied $\sigma^{*}$-antibonding orbital on $\mathrm{C} 3-\mathrm{H}$, and on the $\mathrm{C} 4 \equiv \mathrm{C} 5, \mathrm{C} 6 \equiv \mathrm{C} 7$ triple bonds. Similarly, attack of $\mathrm{CH}_{3} \mathrm{OO}$ and $\mathrm{HO}^{*}$ radicals on $\alpha$-vetivone demonstrates that $\mathrm{H}$-abstraction reactions are also more feasible than the addition ones with $\Delta H$ values of -7.3 and $-41.9 \mathrm{kcal} \mathrm{mol}^{-1}$, respectively. For all considered reactions, the antioxidant molecules preferentially interact with $\mathrm{HO}^{*}$ radical.

\section{Introduction}

Essential oils, aromatic and volatile liquids, are principally extracted from various parts (flowers, seed, leaves, fruits...) of numerous natural plants (tea, pepper, ginger, thyme...). ${ }^{1-5}$ They have been attractive subjects for applications in industry (for flavoring food, perfumes, cosmetics, etc.) as well as in pharmaceutical and medicinal domains. ${ }^{6-9}$ The essential oils are generally rich in terpenoid compounds, mainly mono-, sesquiand desquiterpenes which are hydrocarbon or oxygenated compounds. ${ }^{7,10}$ These interesting oils have already been wellknown in a number of applications such as antimicrobial, anticancer, antifungal, antiviral and especially antioxidant.,41-17 For example, the results obtained by 2,2-diphenyl-1-

\footnotetext{
${ }^{a}$ Institute of Research and Development, Duy Tan University, 03 Quang Trung, Danang, Vietnam.E-mail: daoduyquang@gmail.com

${ }^{b}$ The University of Danang, Campus in Kon Tum, 704 Phan Dinh Phung, Kon Tum, Vietnam

${ }^{c}$ Department of Chemistry, The University of Da Nang - University of Science and Technology, 54 Nguyen Luong Bang, Lien Chieu, Danang, Vietnam

$\dagger$ Electronic supplementary information (ESI) available. See DOI: $10.1039 / \mathrm{c} 7 \mathrm{ra04798c}$
}

picrylhydrazyl (DPPH) and nitric oxide scavenging assays clearly indicate that the essential oils isolated from fresh rhizomes of garlic (Allium Sativum) of the family Alliaceae are effective in scavenging free radicals, so they potentially have a powerful antioxidant role. ${ }^{16}$ In the work of Bozin et al. ${ }^{17}$ the antioxidant activities of the essential oils of Lamiaceae species including Ocimum basilicum L., Origanum vulgare L., and Thymus vulgaris $\mathrm{L}$. were evaluated to play a role in a free radical scavenging capacity (RSC), together with effects on lipid peroxidation (LP). The investigated essential oils exhibit high RSC against DPPH radical and inhibit a very strong lipid peroxidation induced by both $\mathrm{Fe}^{2+} /$ ascorbate and $\mathrm{Fe}^{2+} / \mathrm{H}_{2} \mathrm{O}_{2}$. Otherwise, the antioxidant properties of the essential oils extracted from Cleistocalyx operculatus are also well-known. ${ }^{18}$ A variety of organic compounds including monoterpenes, oxygenated monoterpenes, sesquiterpenes, oxygenated desquiterpenes and diterpenes were experimentally identified and measured antioxidant properties on the basis of the scavenging activities of the stable 2,2-diphenyl-1-picrylhydrazyl (DPPH) free radical. ${ }^{18}$ Additionally, the antioxidant mechanism of these three hydrocarbon terpenoid classes including monoterpenes, sesquiterpenes and diterpenes has theoretically been clarified in our previous study. ${ }^{19}$ Some of them ( $\alpha$-terpinene, $\gamma$-terpinene, 
cembrene and abieta-7,13-diene) have promising antioxidant properties. The ability to scavenge reactive oxygen species (ROS), one of essential requirements for antioxidant role, of selected $\alpha$-terpinene was consequently ascertained via its interaction with hydroperoxyl radicals ( $\left.\mathrm{HOO}^{\circ}\right)^{.{ }^{19}}$

Moreover, several experimental works in literature ${ }^{20-23}$ have been discussed that oxygenated compounds available in Cleistocalyx operculatus like falcarinol, $\alpha$-vetivone and so on, represent also as potential health promoting compounds. In fact, falcarinol, one of aliphatic C17-polyacetylenes which can be found in common food plants such as carrot, celeriac, parsnip and parsley, shows a number of interesting bioactivities such as antibacterial, antimycobacterial, and antifungal activity, antiinflammatory, anti-platelet-aggregatory, as well as neuritogenic and serotonergic effects. ${ }^{20,21,23} \alpha$-vetivone, one of the most important constituents isolated and identified from crude vetiver (Vetiveria zizanioides L.) oil, has strong antioxidant activities via DPPH free radical scavenging assay and the $\mathrm{Fe}^{2+}$ metal chelating assay. ${ }^{24}$

Hence, in this paper, our interest is set on two classes namely oxygenated monoterpenes and oxygenated desquiterpenes, whose structures contain oxygen atom. For more detail, the insight into the theoretical mechanism of antioxidant activity of these compounds will be clarified via three mechanisms of antioxidant action including hydrogen atom transfer (HAT), single electron transfer followed by-proton transfer (SET-PT) and sequential proton loss electron transfer (SPLET). First and foremost, the calculations of various thermochemical parameters including bond dissociation enthalpy (BDE), proton affinity (PA), electron transfer enthalpy (ETE) and ionization energy (IE)

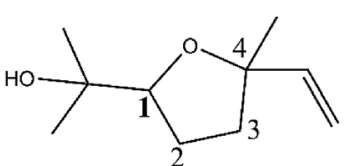<smiles>CC1CCC(O)(C(C)C)CC1</smiles>

Terpinene-4-ol<smiles>C=C(C)C1CC=C(C)C(O)C1</smiles>
Trans-carveol<smiles>CC1(C)CC2C(O)CC1(C)C2(C)C</smiles>

Cis-verbenol

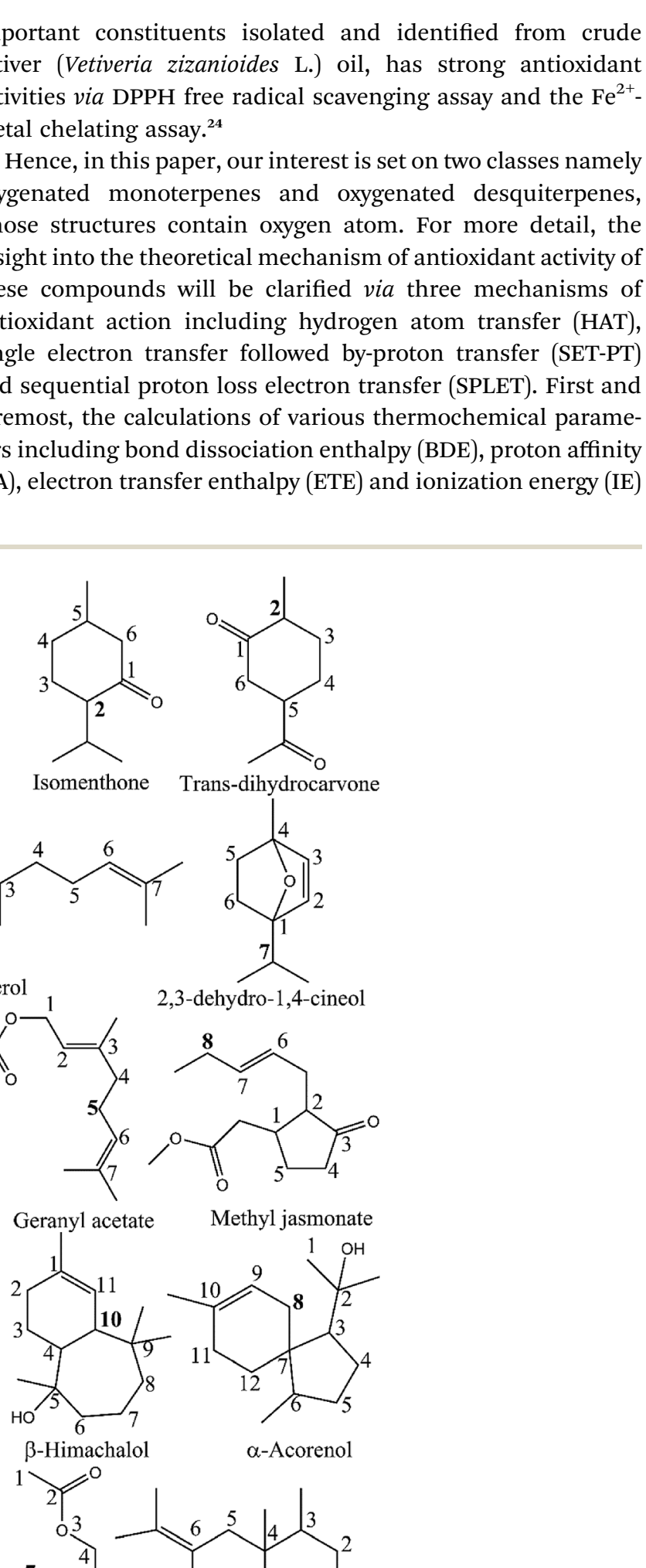

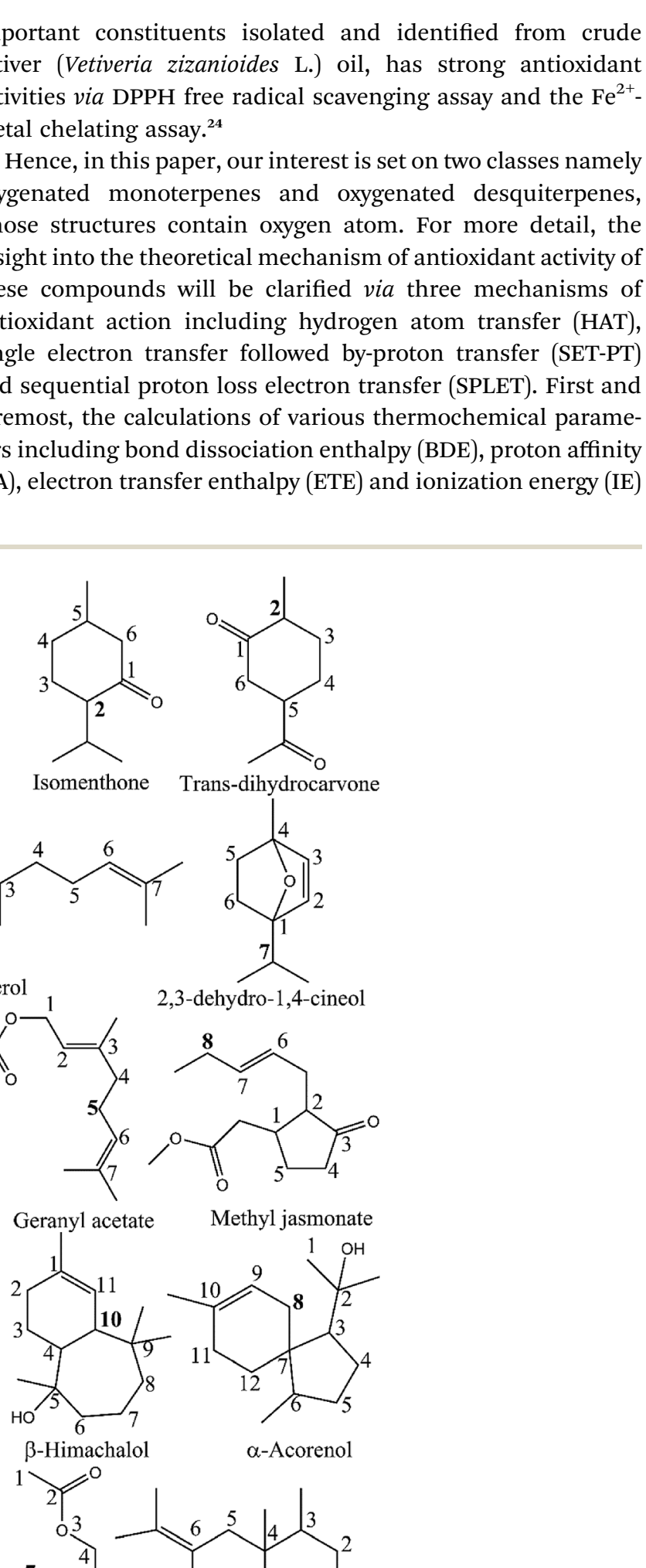

Isomenthone

Trans-dihydrocarvone<smiles>CC(C)=CCCC(C)=CC(C)O</smiles>

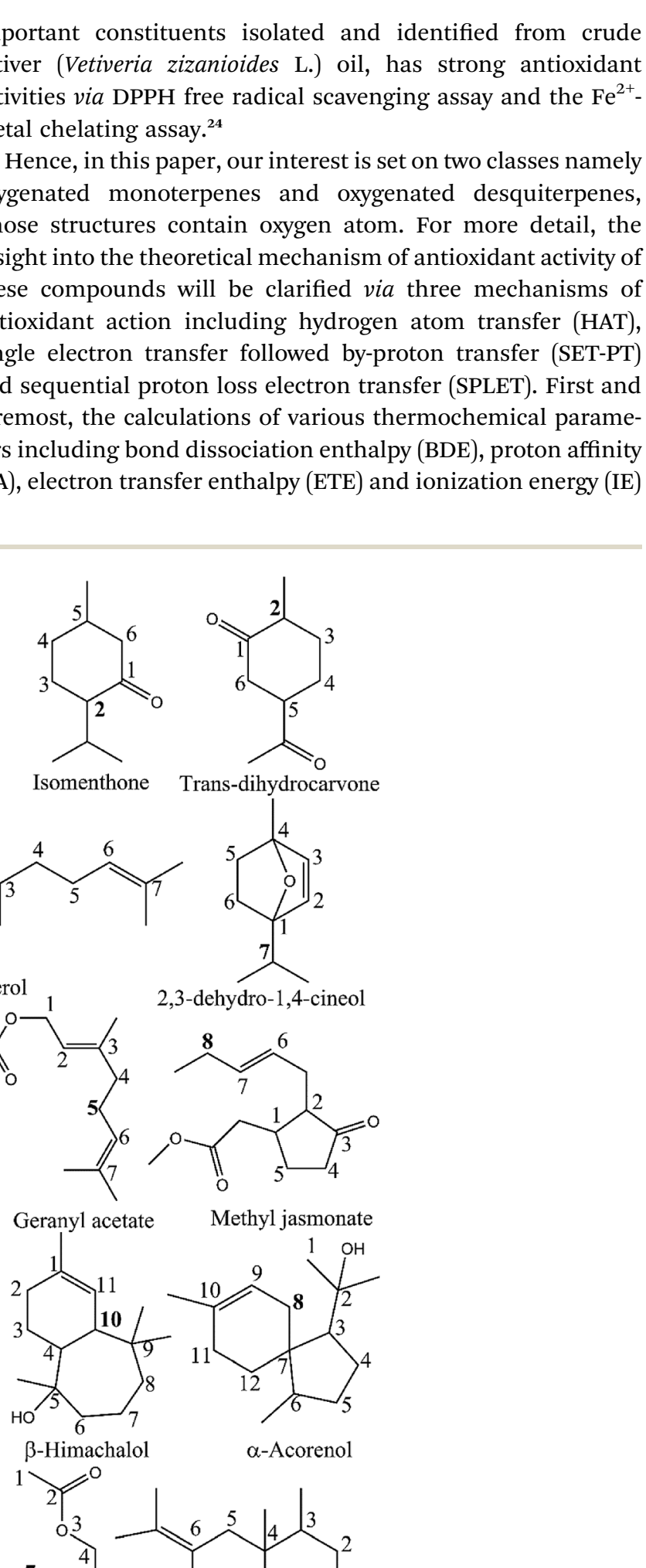<smiles>C=C(C)C1CC=C(C)C(OC(C)=O)C1</smiles>
2,3-dehydro-1,4-cineol<smiles>C=C(C)C(CC=C(C)C)C(C)OC(C)=O</smiles>

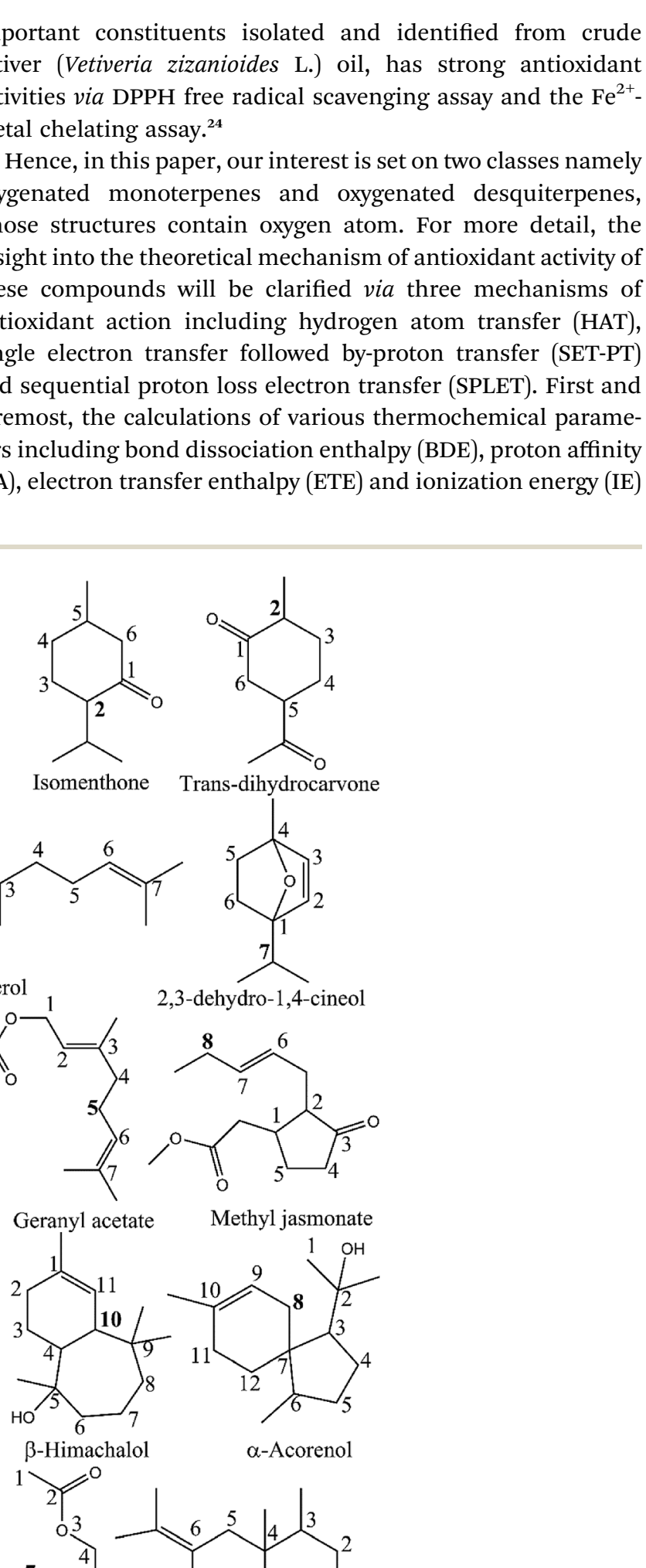

Lavandulyl acetate

Cis-carvyl acetate

$\beta$-Himachalol

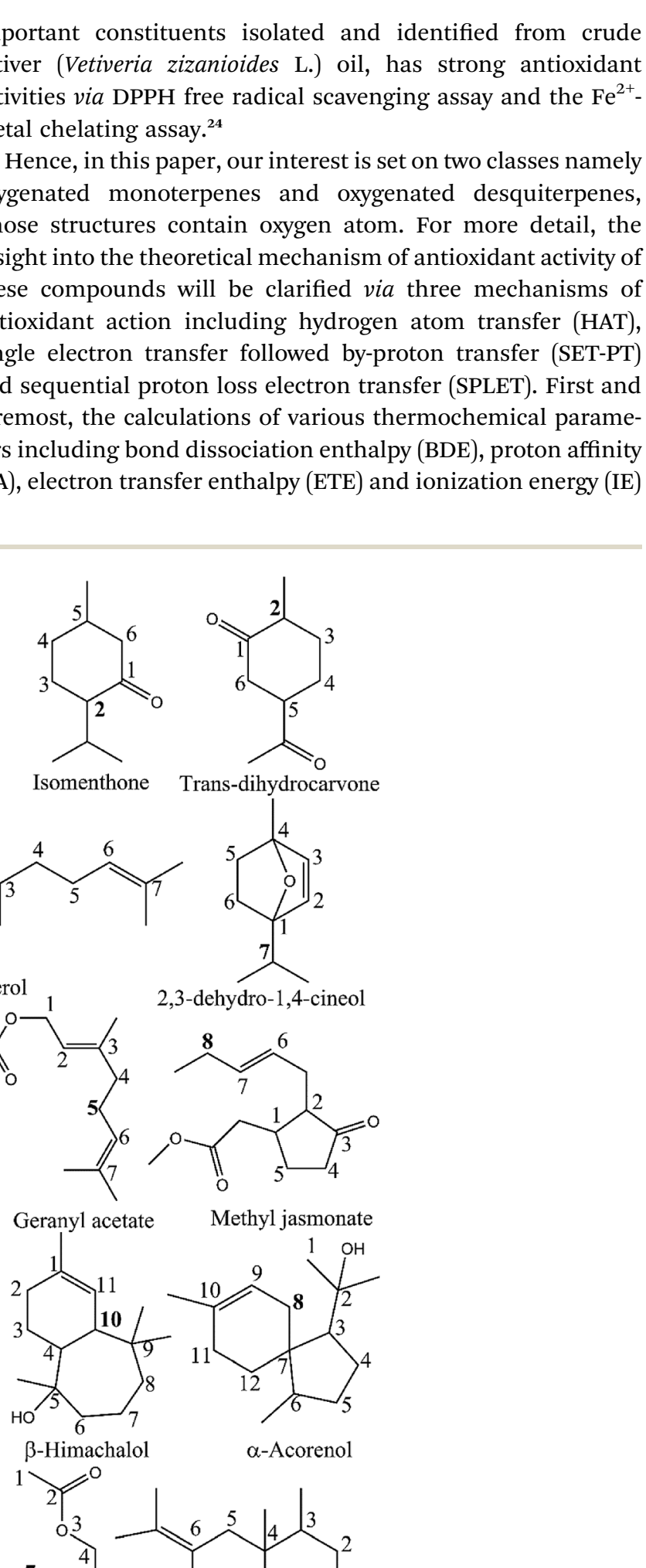

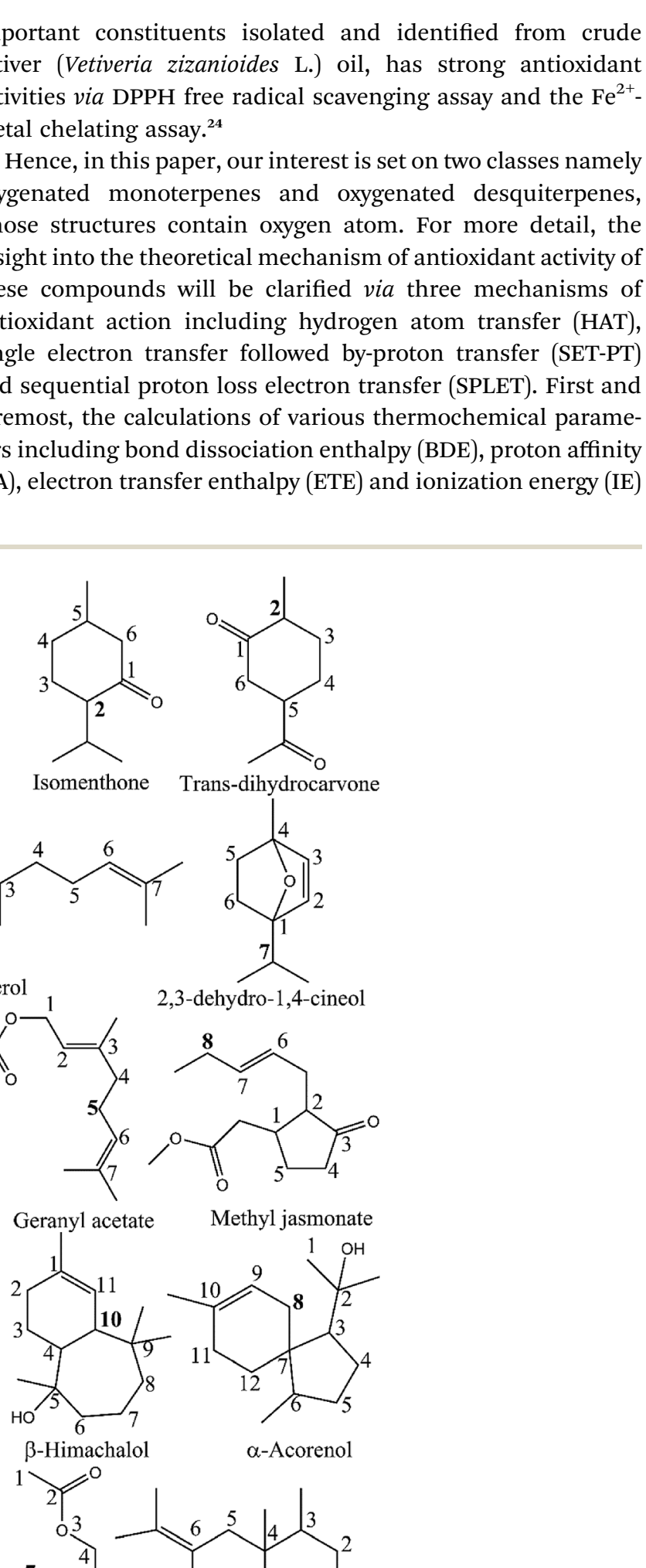

Trans-Nuciferol

$\alpha$-Santalol acetate

Methyl jasmonate

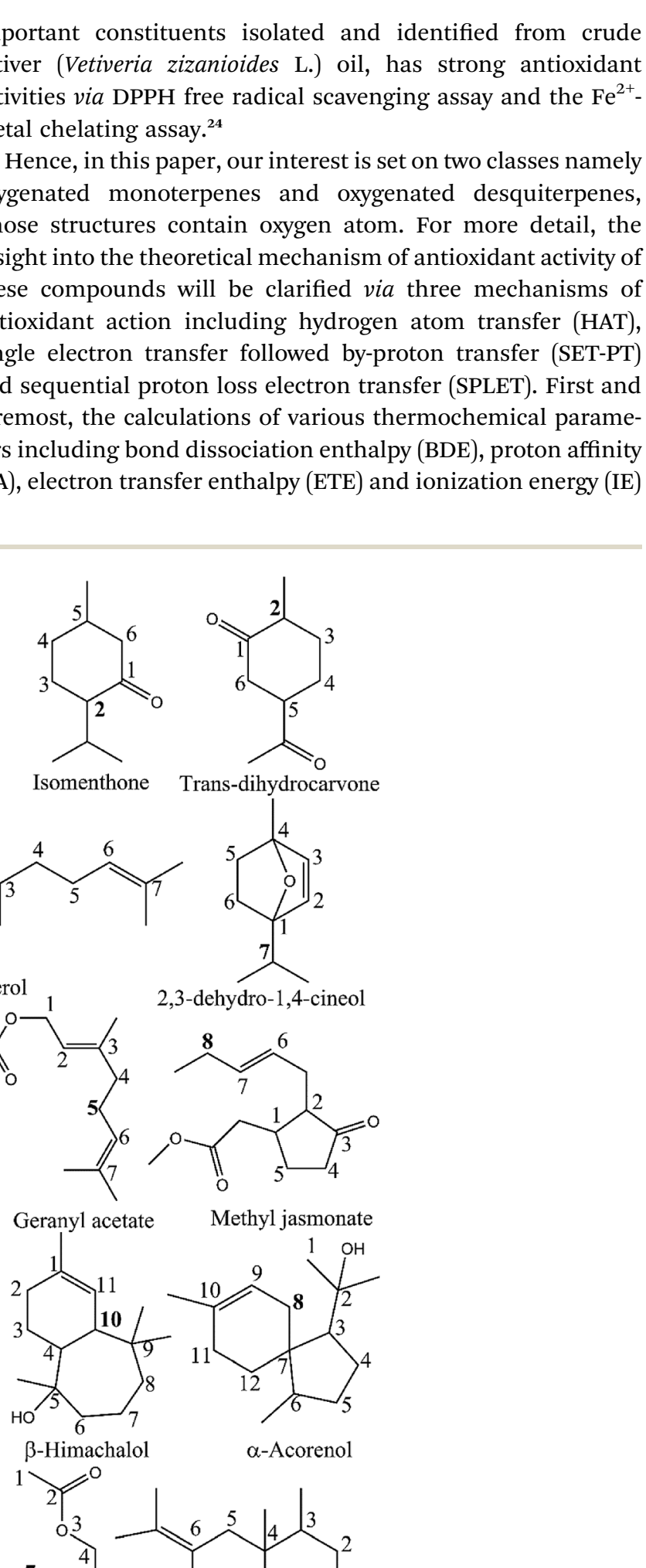<smiles>CC(=CCCC(C)c1ccc(C)cc1)CO</smiles>

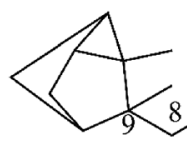<smiles>[3H]C[CH]</smiles><smiles>O=C1C=CC2CCCCC2CC1</smiles>

$\alpha$-Vetivone<smiles>CCCCCCCCCCCCCCCCC(=O)OCC</smiles>

Ethyl hexadecanoate

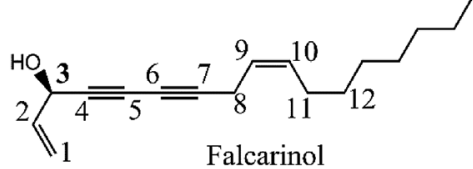

Fig. 1 Chemical structure of 21 studied compounds. 
are performed using the density functional theory (DFT) method at the model chemistry of (RO)B3LYP/6$311++\mathrm{G}(2 \mathrm{df}, 2 \mathrm{p}) / / \mathrm{B} 3 \mathrm{LYP} / 6-311 \mathrm{G}(\mathrm{d}, \mathrm{p})$ in the gas phase, ethanol and water which is a typical polar solvent $(\varepsilon=78.36)$.

In the next step, the global descriptive parameters including chemical potential $(\mu)$, chemical hardness $(\eta)$ and global electrophilicity $(\omega)$ of neutral compounds will be calculated to elucidate their reactivity and stability. Finally, potential energy surface (PES) of all possible addition reactions as well as $\mathrm{H}$-abstraction ones between the most potential antioxidant compounds with $\mathrm{CH}_{3} \mathrm{OO}{ }^{\circ}$ and $\mathrm{HO}^{*}$ radical will be established to give more insights into free radical scavenging mechanism. In parallel, singly-occupied molecular orbital (SOMO), atomic spin density (ASP) and natural bond orbital (NBO) analysis of the optimized transition states will also be taken into account in order to explain clearly the mechanism of reactions.

\section{Computational method}

All calculations were performed using the Gaussian 09 software. $^{25}$ The geometry optimization and the vibrational frequency calculation of each compound and the corresponding radical, cationic radical and anion were primarily performed at the B3LYP/6-311G(d,p) level of theory. Their single point electronic energies were then calculated at the restricted-open shell (RO)B3LYP/6-311++G(2df,2p) level of theory. Generally, three common mechanisms of antioxidant action leading the same final products have been proposed and widely accepted as follows: ${ }^{19,26}$
- Hydrogen atom transfer (HAT):

$$
\mathrm{R}-\mathrm{H} \rightarrow \mathrm{R}^{\cdot}+\mathrm{H}^{\bullet}(\mathrm{BDE})
$$

- Single electron transfer followed by proton transfer (SET-PT)

$$
\begin{aligned}
& \mathrm{R}-\mathrm{H} \rightarrow \mathrm{RH}^{+\cdot}+\mathrm{e}^{-}(\mathrm{IE}) \\
& \mathrm{RH}^{+\cdot} \rightarrow \mathrm{R}^{\cdot}+\mathrm{H}^{+}(\mathrm{PDE})
\end{aligned}
$$

- Sequential proton loss electron transfer (SPLET)

$$
\begin{gathered}
\mathrm{R}-\mathrm{H} \rightarrow \mathrm{R}^{-}+\mathrm{H}^{+}(\mathrm{PA}) \\
\mathrm{R}^{-} \rightarrow \mathrm{R}^{\cdot}+\mathrm{e}^{-}(\mathrm{ETE})
\end{gathered}
$$

The reaction enthalpies of an antioxidant in gas phase at $298.15 \mathrm{~K}$ and $1 \mathrm{~atm}$ are calculated as follows:

$$
\begin{gathered}
\mathrm{BDE}=H\left(\mathrm{R}^{\cdot}\right)+H\left(\mathrm{H}^{\bullet}\right)-H(\mathrm{R}-\mathrm{H}) \\
\mathrm{IE}=H\left(\mathrm{RH}^{\cdot+}\right)+H\left(\mathrm{e}^{-}\right)-H(\mathrm{R}-\mathrm{H}) \\
\mathrm{PDE}=H\left(\mathrm{R}^{\cdot}\right)+H\left(\mathrm{H}^{+}\right)-H\left(\mathrm{RH}^{\cdot+}\right) \\
\mathrm{PA}=H\left(\mathrm{R}^{-}\right)+H\left(\mathrm{H}^{+}\right)-H(\mathrm{R}-\mathrm{H}) \\
\mathrm{ETE}=H\left(\mathrm{R}^{\bullet}\right)+H\left(\mathrm{e}^{-}\right)-H\left(\mathrm{R}^{-}\right)
\end{gathered}
$$

Table 1 The $\mathrm{C}-\mathrm{H}$ bond dissociation enthalpy (BDE) in different media and PDEs in the gas phase of studied compounds using (RO)B3LYP/6$311++G(2 d f, 2 p) / / B 3 L Y P / 6-311 G(d, p)$ model chemistries

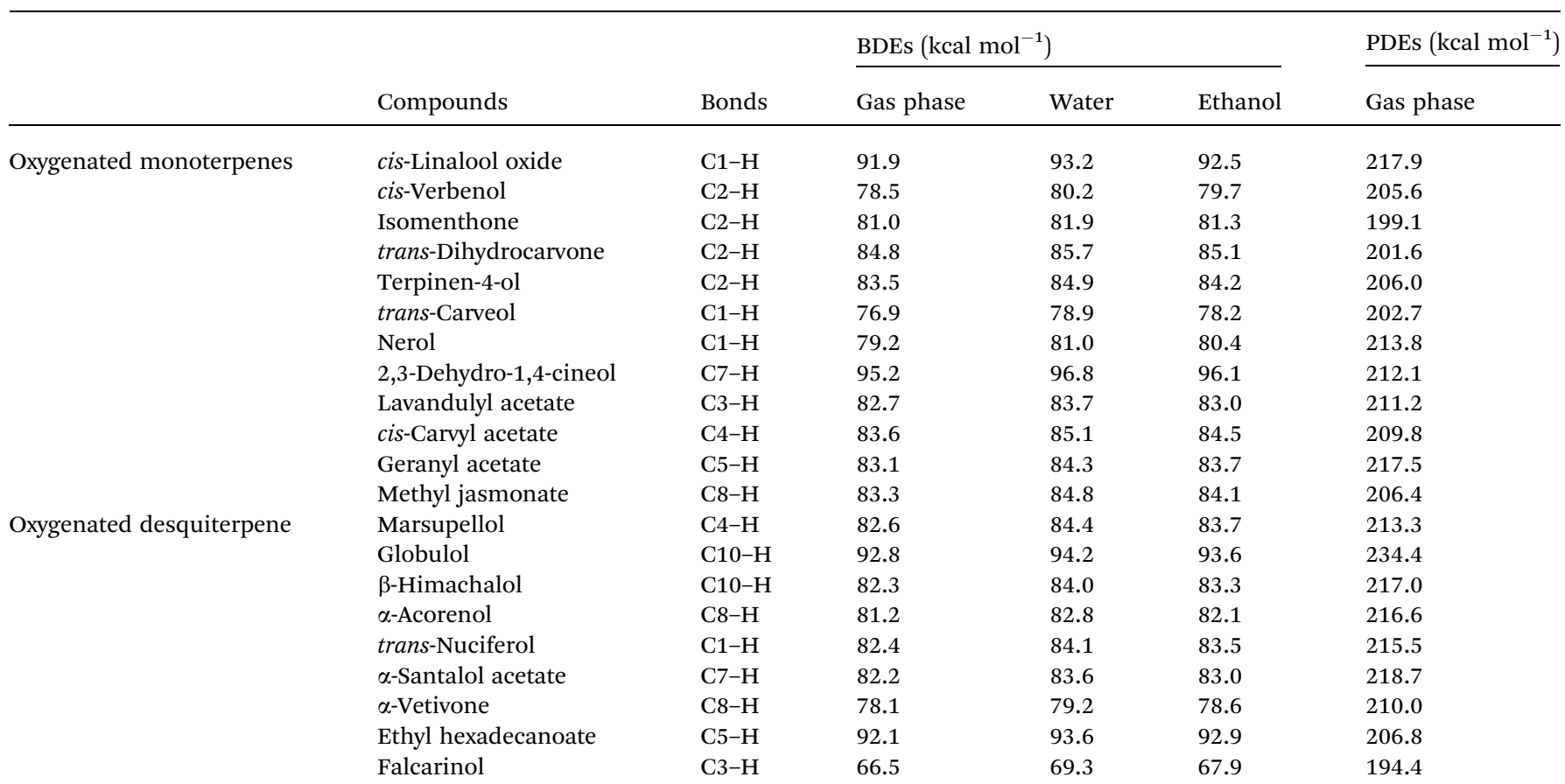


Table 2 Vertical ionization energy (IE), electron affinity (EA), chemical potential $(\mu)$, chemical hardness $(\eta)$ and global electrophilicity $(\omega)$ calculated at B3LYP/6-311++G(2df,2p)//B3LYP/6-311G(d,p) model chemistries (all parameters are in $\mathrm{eV}$ )

\begin{tabular}{llllll}
\hline Compounds & IE & EA & $\mu$ & $\eta$ & $\omega$ \\
\hline cis-Linalool oxide & 8.76 & -0.42 & -4.17 & 4.59 & 1.89 \\
cis-Verbenol & 8.40 & -0.44 & -3.98 & 4.42 & 1.79 \\
Isomenthone & 8.69 & -0.38 & -4.15 & 4.53 & 1.91 \\
trans-Dihydrocarvone & 8.69 & -0.25 & -4.22 & 4.47 & 1.99 \\
Terpinen-4-ol & 8.65 & -0.42 & -4.12 & 4.54 & 1.87 \\
trans-Carveol & 8.52 & -0.39 & -4.07 & 4.45 & 1.86 \\
Nerol & 8.13 & -0.51 & -3.81 & 4.32 & 1.68 \\
2,3-Dehydro-1,4-cineol & 8.95 & -0.50 & -4.23 & 4.72 & 1.89 \\
Lavandulyl acetate & 8.27 & -0.49 & -3.89 & 4.38 & 1.73 \\
cis-Carvyl acetate & 8.47 & -0.39 & -4.04 & 4.43 & 1.84 \\
Geranyl acetate & 8.15 & -0.45 & -3.85 & 4.30 & 1.72 \\
Methyl jasmonate & 8.42 & -0.29 & -4.06 & 4.36 & 1.90 \\
Marsupellol & 8.49 & -0.55 & -3.97 & 4.52 & 1.75 \\
Globulol & 8.14 & -0.39 & -3.88 & 4.27 & 1.76 \\
$\beta$-Himachalol & 8.21 & -0.38 & -3.92 & 4.29 & 1.79 \\
$\alpha$-Acorenol & 8.09 & -0.67 & -3.71 & 4.38 & 1.57 \\
trans-Nuciferol & 8.02 & -0.35 & -3.83 & 4.19 & 1.76 \\
$\alpha$-Santalol acetate & 8.27 & -0.34 & -3.97 & 4.31 & 1.83 \\
$\alpha$-Vetivone & 8.06 & 0.02 & -4.04 & 4.02 & 2.03 \\
Ethyl hexadecanoate & 9.09 & -0.32 & -4.38 & 4.71 & 2.04 \\
Falcarinol & 8.35 & -0.27 & -4.04 & 4.31 & 1.89 \\
& & & & & \\
\hline & & & & &
\end{tabular}

where $H$ is the total enthalpy of the studied species at the temperature of $298.15 \mathrm{~K}$ and usually estimated from the expression below: $H=E_{0}+\mathrm{ZPE}+H_{\text {trans }}+H_{\text {rot }}+H_{\mathrm{vib}}+\mathrm{RT}$.

The $H_{\text {trans }}, H_{\text {rot }}$, and $H_{\text {vib }}$ are the translational, rotational and vibrational contributions to the enthalpy, respectively. $E_{0}$ is the total energy at $0 \mathrm{~K}$ and ZPE is the zero-point vibrational energy.
The enthalpies of $\mathrm{H}$-atom $\left(\mathrm{H}^{*}\right)$, proton $\left(\mathrm{H}^{+}\right)$, and electron $\left(\mathrm{e}^{-}\right)$ are taken from literature. ${ }^{27}$ Vibrational frequencies obtained at the B3LYP/6-311G $(\mathrm{d}, \mathrm{p})$ level of theory were scaled by a factor of $0.9669 .^{28}$ The calculation in solvents was based on integral equation formalism of polarizable continuum model (IEF-PCM) at the same level of theory as in the gas phase. ${ }^{29,30}$ The influence of water and ethanol on the thermodynamic properties was discussed.

To evaluate reactivity and stability of the studied compounds we used global theoretical descriptors that were calculated at B3LYP/6-311++G(2df,2p)//B3LYP/6-311G(d,p). Finite differences method proposed by Pearson and Parr is used to approximately determine chemical potential $(\mu),{ }^{31,32}$ chemical hardness $(\eta)^{33}$ and global electrophilicity $(\omega)^{34}$ on the basis of vertical electron affinity (EA) and ionization energy (IE) of chemical species as follows:

$$
\begin{gathered}
\mu=-\frac{1}{2}(\mathrm{IE}+\mathrm{EA}) \\
\eta=\frac{1}{2}(\mathrm{IE}-\mathrm{EA}) \\
\omega=\frac{\mu^{2}}{2 \eta}
\end{gathered}
$$

Potential energy surface (PES) of the most potential antioxidant compound was also established. The calculation of geometric optimization and vibrational frequencies respectively of transition states, of reactant complexes and of product

\begin{tabular}{|c|c|c|c|c|c|c|c|}
\hline \multirow[b]{2}{*}{ Compounds } & \multirow[b]{2}{*}{ Bonds } & \multicolumn{3}{|c|}{ PA (kcal mol $\left.{ }^{-1}\right)$} & \multicolumn{3}{|c|}{ ETE $\left(\mathrm{kcal} \mathrm{mol}^{-1}\right)$} \\
\hline & & Gas phase & Water & Ethanol & Gas phase & Water & Ethanol \\
\hline cis-Linalool oxide & $\mathrm{O}-\mathrm{H}$ & 369.1 & 57.2 & 74.9 & 51.0 & 70.7 & 89.2 \\
\hline cis-Verbenol & $\mathrm{O}-\mathrm{H}$ & 369.9 & 54.1 & 71.9 & 46.3 & 69.7 & 88.2 \\
\hline Isomenthone & $\mathrm{C} 2-\mathrm{H}$ & 363.2 & 50.5 & 67.9 & 32.3 & 52.2 & 71.1 \\
\hline trans-Dihydrocarvone & $\mathrm{C} 2-\mathrm{H}$ & 356.5 & 50.7 & 68.1 & 43.9 & 57.9 & 76.4 \\
\hline Terpinen-4-ol & $\mathrm{O}-\mathrm{H}$ & 369.6 & 56.2 & 74.0 & 47.5 & 68.4 & 86.9 \\
\hline trans-Carveol & $\mathrm{O}-\mathrm{H}$ & 370.3 & 53.6 & 71.4 & 45.9 & 70.8 & 89.2 \\
\hline Nerol & $\mathrm{C} 4-\mathrm{H}$ & 377.3 & 70.0 & 87.1 & 23.7 & 38.2 & 57.4 \\
\hline 2,3-Dehydro-1,4-cineol & C6-H & 400.7 & 90.1 & 107.7 & 13.6 & 31.9 & 50.6 \\
\hline Lavandulyl acetate & $\mathrm{C} 7-\mathrm{H}$ & 369.2 & 56.4 & 74.0 & 43.6 & 64.2 & 82.8 \\
\hline cis-Carvyl acetate & $\mathrm{C} 8-\mathrm{H}$ & 367.6 & 56.1 & 73.6 & 45.1 & 64.5 & 83.2 \\
\hline Geranyl acetate & $\mathrm{C} 9-\mathrm{H}$ & 370.0 & 56.7 & 74.3 & 42.7 & 63.9 & 82.5 \\
\hline Methyl jasmonate & $\mathrm{C} 2-\mathrm{H}$ & 356.2 & 49.7 & 67.1 & 44.5 & 58.1 & 77.0 \\
\hline Marsupellol & $\mathrm{O}-\mathrm{H}$ & 366.3 & 53.7 & 71.4 & 48.6 & 69.2 & 87.7 \\
\hline Globulol & $\mathrm{O}-\mathrm{H}$ & 365.2 & 55.9 & 73.5 & 49.2 & 66.2 & 84.8 \\
\hline$\beta$-Himachalol & $\mathrm{O}-\mathrm{H}$ & 367.2 & 56.8 & 74.4 & 48.3 & 66.5 & 85.1 \\
\hline$\alpha$-Acorenol & $\mathrm{O}-\mathrm{H}$ & 366.2 & 55.9 & 73.5 & 49.1 & 67.1 & 85.7 \\
\hline trans-Nuciferol & $\mathrm{O}-\mathrm{H}$ & 372.7 & 53.1 & 70.9 & 44.4 & 72.1 & 90.5 \\
\hline$\alpha$-Santalol acetate & $\mathrm{C} 1-\mathrm{H}$ & 369.0 & 56.9 & 74.5 & 43.8 & 63.7 & 82.3 \\
\hline$\alpha$-Vetivone & $\mathrm{C} 8-\mathrm{H}$ & 351.0 & 44.1 & 61.4 & 41.7 & 55.9 & 74.8 \\
\hline Ethyl hexadecanoate & $\mathrm{C} 5-\mathrm{H}$ & 369.1 & 58.7 & 76.2 & 37.6 & 55.8 & 74.4 \\
\hline Falcarinol & $\mathrm{C} 8-\mathrm{H}$ & 341.3 & 41.6 & 58.7 & 46.3 & 51.8 & 70.9 \\
\hline
\end{tabular}

Table 3 Proton affinity (PA) and electron transfer enthalpy (ETE) of studied compounds using (RO)B3LYP/6-311++G(2df,2p)//B3LYP/6-311G(d,p) model chemistries 
complexes were investigated at B3LYP/6-311G(d,p) level of theory for all possible adduction reactions as well as $\mathrm{H}$-abstraction ones.

\section{Results and discussion}

\subsection{Thermochemical parameters characterizing antioxidant capacity}

3.1.1. Antioxidant capacity via hydrogen atom transfer bond dissociation enthalpy. The chemical structures of oxygenated mono- and desquiterpenes, which generally contain oxygen atom and unsaturated bonds, found in the buds of Cleistocalyx operculatus are showed in Fig. 1. In order to evaluate the activity of an antioxidant via hydrogen donating mechanism, the $\mathrm{C}-\mathrm{H}$ and $\mathrm{O}-\mathrm{H}$ homolytic bond dissociation enthalpies (BDEs) which relate to the abilities of donating hydrogen atom and of forming radical species, are taken into account. The lowest BDE is defined for the relevant position of $\mathrm{C}-\mathrm{H} / \mathrm{O}-\mathrm{H}$ where the easiest abstraction hydrogen for free radical scavenging reaction can take place. Hence, BDE is an appropriate descriptor of the antioxidant activity.

As observed in the previous study, ${ }^{19}$ the $\mathrm{C}-\mathrm{H}$ bonds neighboring $\mathrm{C}=\mathrm{C}$ double bonds are detected to be the easiest breaking bonds in comparing to other ones due to the reason that the electron-withdrawing inductive effect $(-I)$ of the $\pi$-bond induces an electron-releasing phenomenon from the carbon atoms, and consequently increases the polarization of the $\mathrm{C}-\mathrm{H}$ bonds. Therefore, these bonds were reasonably

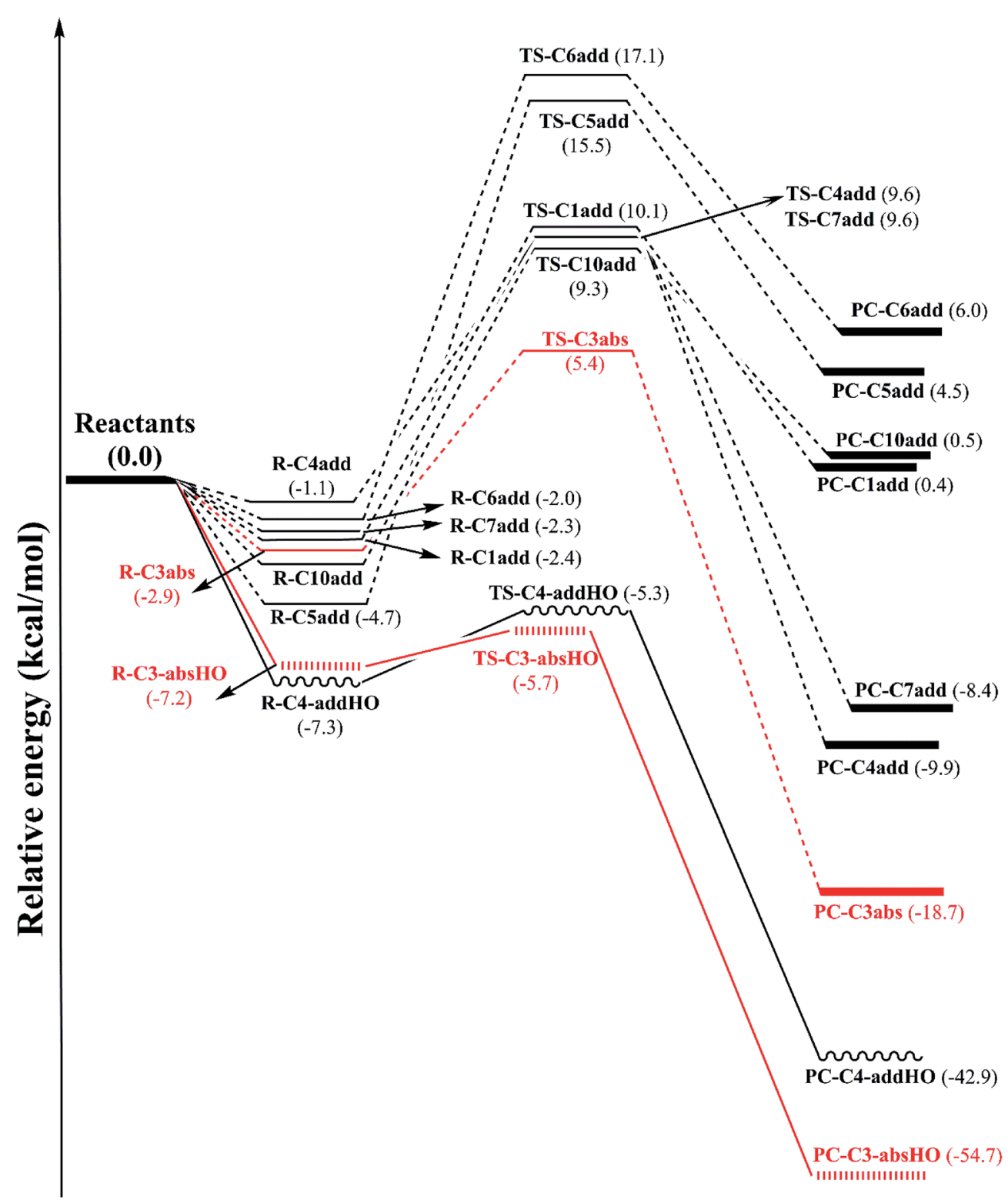

Fig. 2 Potential energy surface (PES) at B3LYP/6-311G (d,p) level of theory of $\mathrm{H}$-abstraction reaction at easiest breaking bond and addition reaction at unsaturated bond positions between $\mathrm{CH}_{3} \mathrm{OO}$, and $\mathrm{HO}$ radicals and falcarinol. (The abbreviation containing $\mathrm{HO}$ indicates for the reactions with $\mathrm{HO}^{\circ}$, the rest is of the ones with $\mathrm{CH}_{3} \mathrm{O} \mathrm{O}^{\circ}$ ). 
selected to compute their strength at the higher level of theory of (RO)B3LYP/6-311++G(2df,2p)//B3LYP/6-311G(d,p). The BDEs of weakest bonds are present in Table 1 . Cartesian coordinates and enthalpies of all parent molecules and resulted radicals, anions optimized at B3LYP/6-311G(d,p) level of theory in the gas phase, water and ethanol are presented in Table S1 ESI. $\dagger$

Table 1 demonstrates that the BDEs $(\mathrm{C}-\mathrm{H})$ of studied compounds vary from 66.5 to $95.2 \mathrm{kcal} \mathrm{mol}^{-1}$. The lowest BDE (C-H) of $66.5 \mathrm{kcal} \mathrm{mol}^{-1}$ is indicated for falcarinol which contains two conjugated triple bonds and two double bonds in its structure. It means that the number of $\mathrm{C}=\mathrm{C}$ double and $\mathrm{C} \equiv \mathrm{C}$ triple bonds present in molecular system has a significant effect on the BDEs. In fact, the lower BDE $(\mathrm{C}-\mathrm{H})$ (i.e. $78.1 \mathrm{kcal} \mathrm{mol}^{-1}$ ) of $\alpha$-vetivone compared to the others is also related to the presence of two conjugated $\pi$-bonds nearby that $\mathrm{C}$ position (as can be seen in Fig. 1). As the number of conjugated double/triple bonds increases, the electrons associated with conjugated systems have more space to delocalize and require less energy to change states. This results are coherent with the previous study. ${ }^{19}$

In addition, the presence of $\mathrm{OH}$ group also contributes to the changing of the BDE values. In fact, the $\mathrm{C}-\mathrm{H}$ bonds located nearby both $\mathrm{OH}$ group and unsaturated bonds possess lower BDE values compared to other ones. For example, the BDEs of cis-verbenol, trans-carveol and nerol are, in principle, lower than $80 \mathrm{kcal} \mathrm{mol} \mathrm{m}^{-1}$, being 79.2, 76.9 and $78.6 \mathrm{kcal} \mathrm{mol}^{-1}$, respectively.

Regarding the effect of solvents on BDEs, there is occurred no remarkable difference between the results computed in the gas phase and two solvents (water and ethanol). For example, the BDEs calculated in the gas phase, water and ethanol of falcarinol are $66.5,69.3$ and $67.9 \mathrm{kcal} \mathrm{mol}^{-1}$, respectively. Similarly, the calculated values in these three phases for transcarveol are 76.9, 78.9 and $78.2 \mathrm{kcal} \mathrm{mol}^{-1}$, respectively. This leads to conclude that hydrogen atom transfer is favored in nonpolar environments.

3.1.2. Antioxidant capacity via electron transfer - ionization energy (IE). Ionization energy which characterizes for electron transfer ability, equally serves as a general parameter for evaluating radical scavenging potency of antioxidants via SET-PT mechanism. The higher the IE is, the more difficult an electron can be removed. The results show the lowest IEs of 8.02, 8.06 and $8.09 \mathrm{eV}$ corresponding to trans-nuciferol, $\alpha$-vetivone and $\alpha$-acorenol, while the highest one of $9.09 \mathrm{eV}$ assigning to ethyl hexadecanoate (Table 2). It means that electron removal from those three molecules is more favorable.

In parallel with IE values, the global reactivity descriptors including chemical potential $(\mu)$, chemical hardness $(\eta)$ and global electrophilicity $(\omega)$ calculated based on IE and EA values give more information about the tendency of selectivity and chemical reactivity of parent compounds and their radical formed via easiest $\mathrm{C}-\mathrm{H}$ breaking bonds (data present in Table 2). For example, chemical hardness $(\eta)$, which is defined as the resistance of cloud polarization or deformation of chemical species, is used to predict the reactivity of molecules. The lowest value of hardness means the highest reactivity. Regarding the hardness values present in Table $2, \alpha$-vetivone is seen to be the most reactive in comparison with the hardness of the other compounds noted $4.02 \mathrm{eV}$. In terms of global electrophilicity $(\omega)$ representing the capacity of a system to acquire an electron, a higher $\omega$ value demonstrates the more reactive molecule. Among these studied compounds, $\alpha$-vetivone and ethyl hexadecanoate show as the most reactive ones with the $\omega$ value of 2.03 and $2.04 \mathrm{eV}$, respectively.

The following step of electron transfer via SET-PT mechanism is proton transfer process from $\mathrm{C}-\mathrm{H}$ group of the formed cationic radical that is characterized by proton dissociation enthalpy (PDE). The PDE values for deprotonation of all cationic

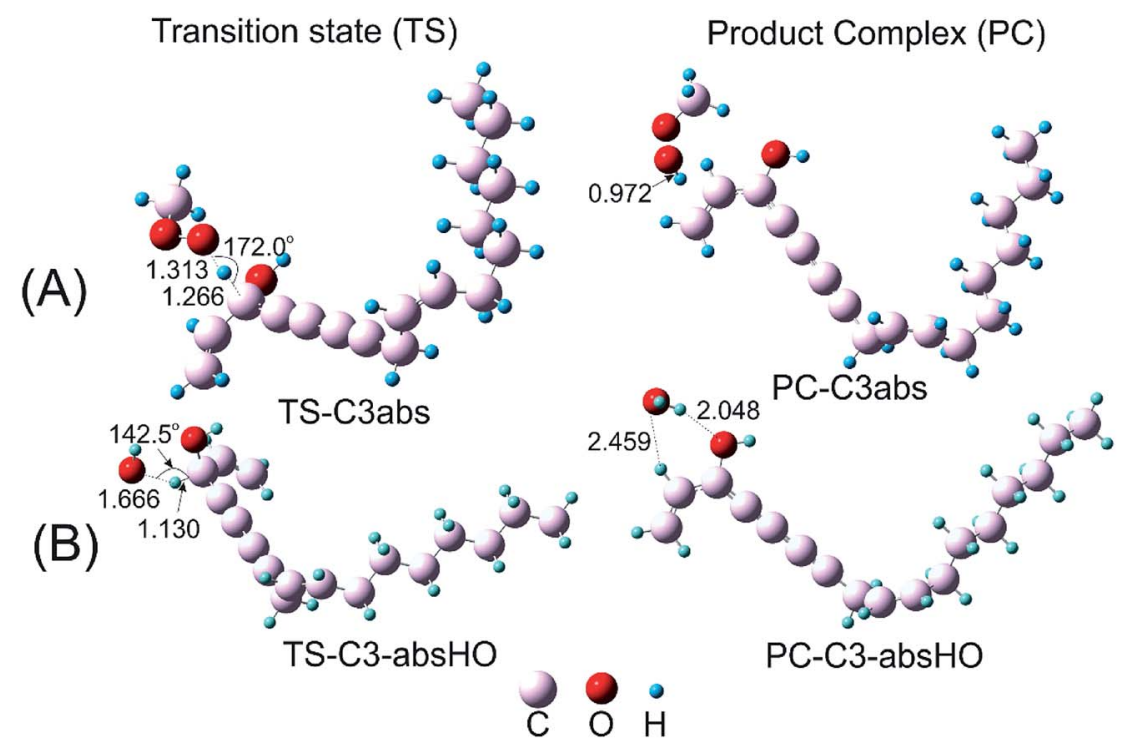

Fig. 3 Optimized geometries of transition state (TS) and product complex (PC) species for the $\mathrm{H}$-atom abstraction between falcarinol and (A) $\mathrm{CH}_{3} \mathrm{OO}{ }^{\circ}$ and $(\mathrm{B}) \mathrm{HO} \cdot$ radical at the $\mathrm{B} 3 \mathrm{LYP} / 6-311 \mathrm{G}(\mathrm{d}, \mathrm{p})$ level of theory, (distances are given in angstroms). 
radical species are displayed in Table 1 and indicates that the easiest deprotonation generally found at the $\mathrm{C}-\mathrm{H}$ position with the lowest BDE. As a result, the lowest PDEs are 194.4 and $199.1 \mathrm{kcal} \mathrm{mol}^{-1}$ corresponding to the cationic radical formed from falcarinol and isomenthone, respectively. It is noted that falcarinol demonstrates both the easiest homolytic and heterolytic H-dissociation.

3.1.3. Antioxidant capacity via sequential proton loss electron transfer (SPLET) - proton affinity (PA) and electron transfer enthalpy (ETE). Proton affinity (PA) and electron transfer enthalpy (ETE) are two physicochemical parameters used to examine antioxidant activity via SPLET mechanism. In principle, from mother compounds, a SPLET mechanism occurs via two successive steps which are a proton loss process characterized by PA value, and then an electron transfer symbolized by ETE value. The lower the PA is, the higher the antioxidant activity can be marked. The PAs of all possible bonds breaking were firstly calculated by the semi-empirical PM6 method to find out the easiest deprotonation positions. The PAs of relevant bonds were then computed at higher (RO)

(A)

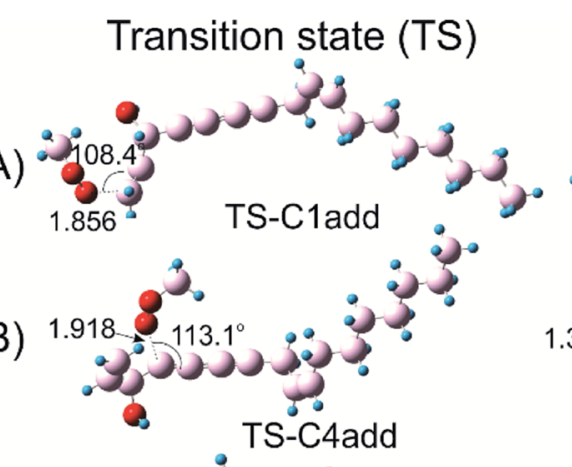

\section{Product complex (PC)}

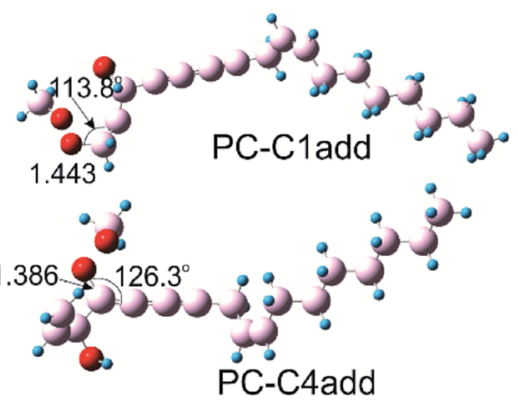

(C)
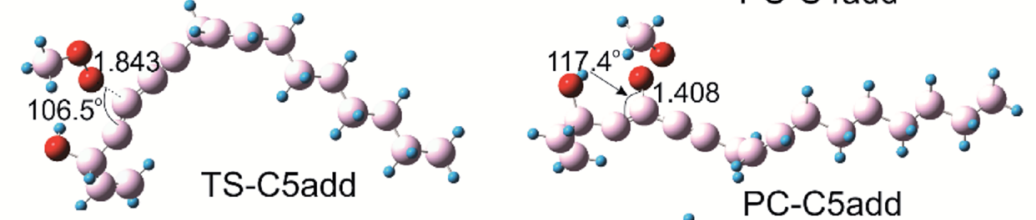

(D)
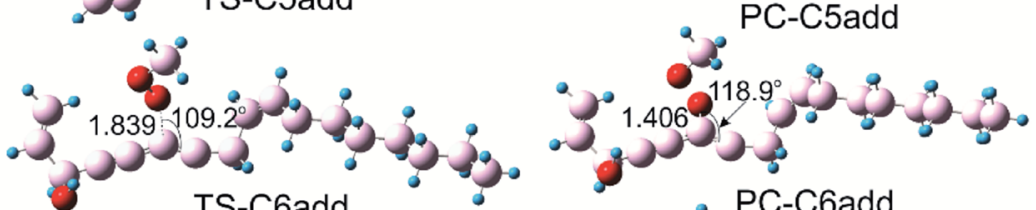

(E)
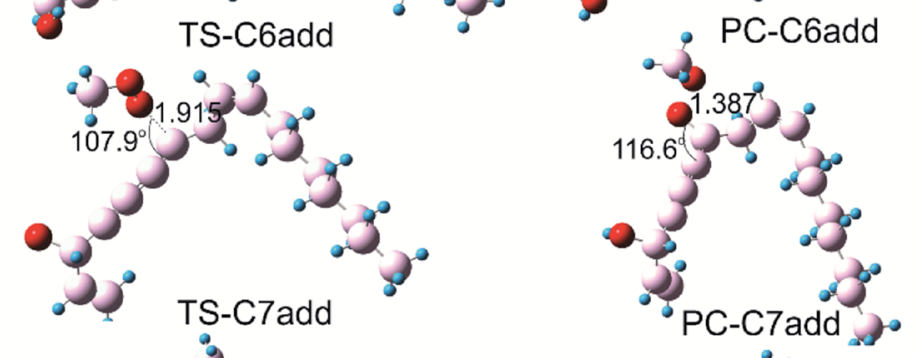

(F) - $\int_{0}^{0}$

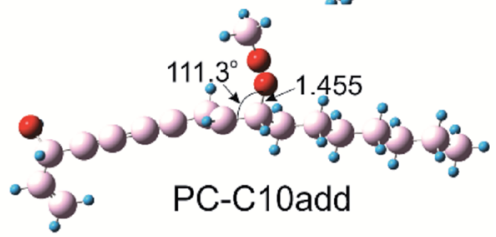

TS-C10add

(G)

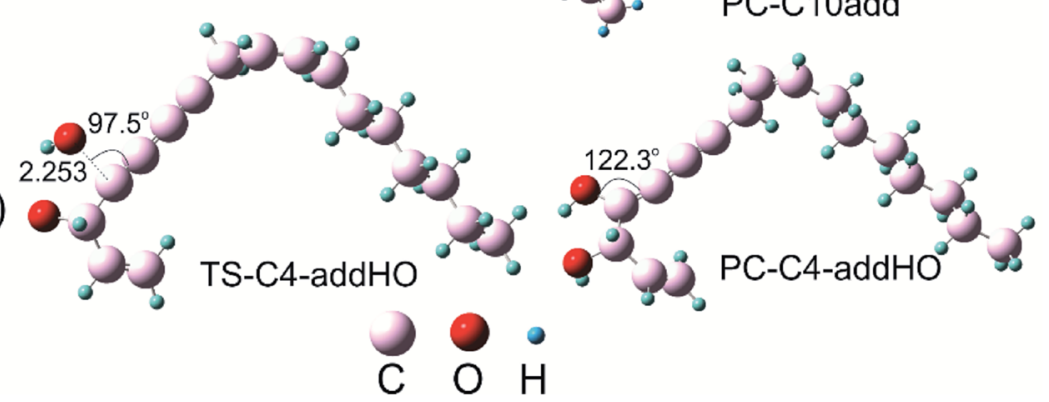

Fig. 4 Optimized geometries of transition state (TS) and product complex (PC) of addition reaction at unsaturated bond positions between falcarinol and $\mathrm{CH}_{3} \mathrm{OO}{ }^{\circ}$ radical $(\mathrm{A}-\mathrm{F})$ and $\mathrm{HO}{ }^{*}$ radical $(\mathrm{G})$. All calculations were performed at $\mathrm{B} 3 \mathrm{LYP} / 6-311 \mathrm{G}(\mathrm{d}, \mathrm{p})$ level of theory. 
Table 4 Reaction enthalpies $(\Delta H)$ and Gibbs energies $(\Delta G)$ (in $\mathrm{kcal} \mathrm{mol}^{-1}$ ) for the $\mathrm{H}$-atom abstraction at easiest $\mathrm{H}$-breaking bond and the addition reactions between falcarinol (FALC) and $\alpha$-vetivone (VET) and $\mathrm{CH}_{3} \mathrm{OO}{ }^{\circ}$ and $\mathrm{HO}^{\circ}$ radicals

\begin{tabular}{lll}
\hline Reactions & $\Delta H, \mathrm{kcal} \mathrm{mol}^{-1}$ & $\Delta G, \mathrm{kcal} \mathrm{mol}^{-1}$ \\
\hline FALC-C3H + $\mathrm{CH}_{3} \mathrm{OO}^{\circ}$ & -18.7 & -10.0 \\
FALC-C10 + $\mathrm{CH}_{3} \mathrm{OO}^{\circ}$ & 0.5 & 12.6 \\
FALC-C7 + $\mathrm{CH}_{3} \mathrm{OO}^{\circ}$ & -8.4 & 3.1 \\
FALC-C6 + $\mathrm{CH}_{3} \mathrm{OO}^{\circ}$ & 6.0 & 18.0 \\
FALC-C5 + $\mathrm{CH}_{3} \mathrm{OO}^{\circ}$ & 4.5 & 16.6 \\
FALC-C4 + $\mathrm{CH}_{3} \mathrm{OO}^{\circ}$ & -9.9 & 1.7 \\
FALC-C1 + $\mathrm{CH}_{3} \mathrm{OO}^{\circ}$ & 0.4 & 12.4 \\
FALC-C3H + & -54.7 & -47.1 \\
FALC-C4 + $\mathrm{HO}^{\circ}$ & -42.9 & -32.2 \\
VET-C8H + $\mathrm{CH}_{3} \mathrm{OO}^{\circ}$ & -7.3 & 1.5 \\
VET-C8H + $\mathrm{HO}^{\circ}$ & -41.9 & -36.2 \\
VET-C9 + $\mathrm{CH}_{3} \mathrm{OO}^{\circ}$ & 4.8 & 18.0 \\
VET-C9 + $\mathrm{HO}^{\circ}$ & -25.3 & -14.3 \\
& &
\end{tabular}

B3LYP/6-311++G(2df,2p)//B3LYP/6-311G(d,p) level of theory. The obtained results are given in Table 3 .

It is generally observed that heterolytic cleavage is favored at $\mathrm{O}-\mathrm{H}$ and $\mathrm{C}-\mathrm{H}$ position located nearby $\mathrm{C}=\mathrm{C}$ double bonds. The best antioxidant based on SPLET mechanism is falcarinol with the PAs computed in the gas phase of $341.3 \mathrm{kcal} \mathrm{mol}^{-1}$. In the meantime, when calculating in polar solvents, one observed a dramatic decrease in PAs by comparison with the values measured in the gas phase. In fact, the PA of cis-linalool oxide in the gas phase is $369.1 \mathrm{kcal} \mathrm{mol}^{-1}$ while its values in water and ethanol are 57.2 and $74.9 \mathrm{kcal} \mathrm{mol}^{-1}$, respectively. Similarly, the PAs of falcarinol are $341.3,41.6$ and $58.7 \mathrm{kcal} \mathrm{mol}^{-1}$ assigned to the calculation in the gas phase, water and ethanol, respectively. This observation can be explained by the higher solvation enthalpy of proton in water and ethanol compared to that in the gas phase, and also it is in a good agreement with the results obtained in previous studies. ${ }^{19,26,35}$ Indeed, Thong et al. showed the PAs of $\alpha$-mangostin are 326.0 and $23.6 \mathrm{kcal} \mathrm{mol}^{-1}$ at B3LYP/ $6-31+G(d, p)$ level of theory in the gas phase and water, respectively. ${ }^{26}$ The PAs obtained for a hydroxylchalcone by Wang and coworkers are $354.6 \mathrm{kcal} \mathrm{mol}^{-1}$ in the gas phase and $58.5 \mathrm{kcal}$ $\mathrm{mol}^{-1}$ in water at B3LYP/6-311++G(2d,2p) level of theory. ${ }^{35}$ In conclusion, the deprotonation process of an antioxidant is favored in polar environments.

Regarding the electron transfer enthalpy (ETE) which represents the electron donating ability of anion formed in the first step of the SPLET mechanism, one observed that the ETEs in the gas phase (as seen in Table 3) are relatively lower than IEs (data in Table 2). For example, ETE of cis-linalool oxide in the gas phase is $51.0 \mathrm{kcal} \mathrm{mol}^{-1}$ while IE is $206.1 \mathrm{kcal} \mathrm{mol}^{-1}$ (or $8.94 \mathrm{eV}$ ). It means that the electron transfer from anionic form is more favorable than that from neutral one. This is coherent with the results reported in previous studies. ${ }^{19,26,36,37}$

Among studied compounds, falcarinol seems to be the most efficient antioxidant molecule via both HAT and SPLET mechanisms. And $\alpha$-vetivone is also a promising antioxidant compound. Therefore, in the following section, falcarinol and $\alpha$-vetivone are considered as a model molecule to investigate their interaction with $\mathrm{CH}_{3} \mathrm{OO}$ and $\mathrm{HO}^{*}$ radicals which are chosen as representative free radical model for $\mathrm{ROO}^{\circ}$ and $\mathrm{RO}^{\circ}$ one.

\subsection{Interaction of typical free radicals with potential antioxidant molecules}

Falcarinol which contains two conjugated triple bonds and two double bonds shows as the easiest $\mathrm{H}$-donating compound with the BDE (C3-H) in the gas phase of $66.5 \mathrm{kcal} \mathrm{mol}^{-1}$. It can play a role in scavenging free radical via either $\mathrm{H}$-abstraction at $\mathrm{C} 3-\mathrm{H}$ or addition at the unsaturated bonds. Reactions between falcarinol and $\mathrm{CH}_{3} \mathrm{OO}$ radical will be discussed in turn the $\mathrm{H}$-abstraction channel at $\mathrm{C} 3-\mathrm{H}$ and the addition channel at $\mathrm{C} 1=\mathrm{C} 2, \mathrm{C} 9=\mathrm{C} 10$ double and $\mathrm{C} 4 \equiv \mathrm{C} 5, \mathrm{C} 6 \equiv \mathrm{C} 7$ triple bonds (see Fig. 1). The potential energy surfaces (PES) of these reactions are established and displayed in Fig. 2. All optimized structures and the corresponding energies of the species related to the mentioned reaction were computed at B3LYP/6-311G(d,p) level. IRC plots for all transition states related to reactions of $\mathrm{CH}_{3} \mathrm{OO}{ }^{\circ}$ and $\mathrm{HO}^{\circ}$ radicals with falcarinol are presented in Fig. S2 of ESI..$^{\dagger}$

3.2.1. Hydrogen abstraction reaction by free radical at the easiest $\mathrm{H}$-donating position. $\mathrm{H}$-abstraction reaction by $\mathrm{CH}_{3} \mathrm{OO}$ ' and $\mathrm{HO}^{\circ}$ radical at $\mathrm{C} 3-\mathrm{H}$ of falcarinol (FALC-H) (see Fig. 1) is demonstrated as below:

$$
\mathrm{CH}_{3} \mathrm{OO}^{*} / \mathrm{HO}^{\bullet}+\mathrm{FALC}^{-} \mathrm{H} \rightarrow \mathrm{FALC}^{\bullet}+\mathrm{CH}_{3} \mathrm{OOH} / \mathrm{H}_{2} \mathrm{O}
$$

PES of $\mathrm{H}$-abstraction and radical addition to unsaturated bonds reactions of falcarinol with $\mathrm{CH}_{3} \mathrm{OO}^{\circ}$ and $\mathrm{HO}^{\circ}$ radical is displayed in Fig. 2. All the optimized geometries of transition state (TS) and product complex (PC) are shown in Fig. 3 and 4. TS structure of $\mathrm{H}$-abstraction reaction between falcarinol with DPPH radical is also presented in Fig. S4 of ESI. $\dagger$

The $\mathrm{H}$-atom transfer from $\mathrm{C} 3-\mathrm{H}$ bond of falcarinol to the $\mathrm{CH}_{3} \mathrm{OO}{ }^{\circ}$ radical is occurred in initiation step and demonstrated as an important one in interrupting the chain reactions. ${ }^{38}$ In the $\mathrm{H}$-abstraction reaction, the $\mathrm{CH}_{3} \mathrm{OO}$ radical and falcarinol reactants can form a hydrogen-bonded reactant complex (R-C3) at energy lying below the separated reactants by -2.3 $\mathrm{kcal} \mathrm{mol}^{-1}$. In this state, a hydrogen bond is generated between O-atom of $\mathrm{CH}_{3} \mathrm{OO}$ and $\mathrm{H}$-atom at $\mathrm{C} 3-\mathrm{H}$ of falcarinol, and $\mathrm{CH}_{3} \mathrm{OO} \cdots \mathrm{H}-\mathrm{C} 3$ distance is $2.447 \AA$ (as seen in Fig. 3). Then, the $\mathrm{H}$-atom of falcarinol tends to form a chemical bond with the $\mathrm{O}$-atom of the radical via a transition state (TS-C3abs) lying at $5.4 \mathrm{kcal} \mathrm{mol}{ }^{-1}$ above the reactants where the $\mathrm{CH}_{3} \mathrm{OO} \cdots \mathrm{H}-\mathrm{C} 3$ distance is shorter. The $\mathrm{H}$-atom is situated in the middle of $\mathrm{O}$ and $\mathrm{C} 3$ atoms and the $\mathrm{CH}_{3} \mathrm{OO} \cdots \mathrm{H}$ and $\mathrm{H}-\mathrm{C} 3$ distance are 1.313 and $1.266 \AA$, respectively. The $\mathrm{C} 3-\mathrm{H}-\mathrm{O}$ angle is relatively bent, being $172^{\circ}$ (Fig. 3). After passing these states, the reaction pathway reaches the product complex (PC-C3abs) containing FALC radical and $\mathrm{CH}_{3} \mathrm{OOH}$ at $-18.7 \mathrm{kcal} \mathrm{mol}^{-1}$ below the reactants, in which a covalent chemical bond of $0.972 \AA$ is formed between $\mathrm{O}$ and $\mathrm{H}$-atom. It is worth noting that the $\mathrm{H}$-abstraction reaction at the easiest breaking bond requires lower reaction barriers compared to the addition ones (see Fig. 2). In addition, the Gibbs energy $(\Delta G)$ presented in Table 4 


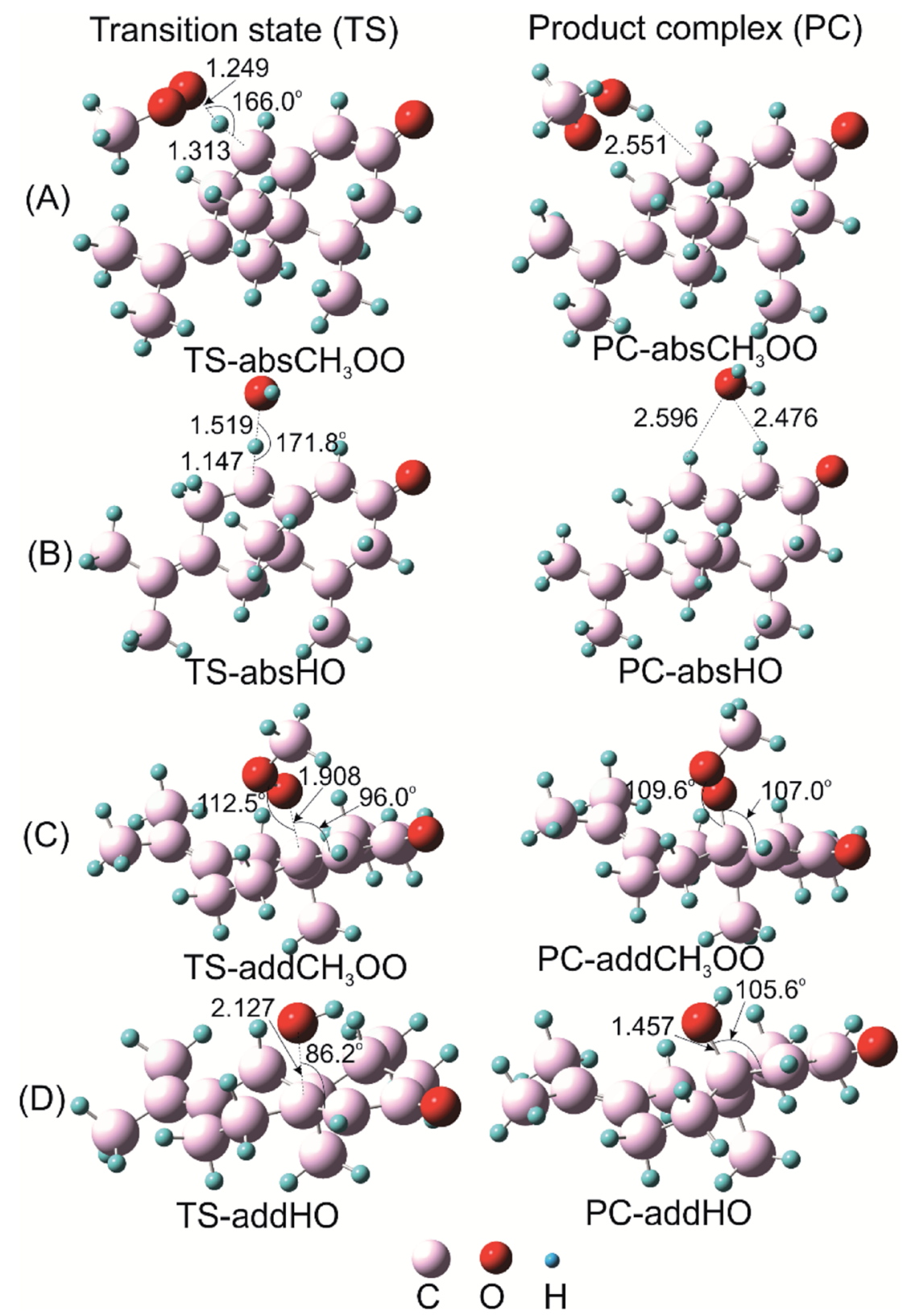

Fig. 5 Optimized geometries of transition states (TS) and product complexes (PC) of $\mathrm{H}$-atom abstraction reactions of $\alpha$-vetivone with (A) $\mathrm{CH}_{3} \mathrm{OO}$ radical, (B) $\mathrm{HO}^{\circ}$ radical at $\mathrm{C} 8-\mathrm{H}$ position; and of addition reactions to double bonds for (C) $\mathrm{CH}_{3} \mathrm{OO}{ }^{\circ}$ radical and (D) $\mathrm{HO}^{\circ}$ radical at $\mathrm{C} 9$ position.

shows that the $\mathrm{H}$-abstraction reaction by $\mathrm{CH}_{3} \mathrm{OO}$ radical is exergonic with a negative $\Delta G$ value of $-10.0 \mathrm{kcal} \mathrm{mol}^{-1}$.

Additionally, the radical scavenging ability of falcarinol has been studied via another reactive radical such as $\mathrm{HO}^{\circ}$. $\mathrm{H}$-atom abstraction at $\mathrm{C} 3-\mathrm{H}$ position and addition reactions at $\mathrm{C} 4 \equiv \mathrm{C} 5$ triple bond that showed as the most feasible ones in the reaction with $\mathrm{CH}_{3} \mathrm{OO}^{\circ}$ were taken into account. These reactions are chosen because they are shown as the most feasible ones in terms of energy. These reactions pass transition states, called TS-C3-absHO and TS-C4-addHO, at -5.7 and $-5.3 \mathrm{kcal} \mathrm{mol}^{-1}$ lying under reactants that are followed by product complexes, namely PC-C3-absHO and PC-C4-addHO, at considerably negative energy of -54.7 and $-42.9 \mathrm{kcal} \mathrm{mol}^{-1}$, respectively. It is noted that these reactions are exergonic, showing negative $\Delta G$ values of -47.1 and $-32.2 \mathrm{kcal} \mathrm{mol}^{-1}$, in sequence (Table 4). In comparison with the reactions with $\mathrm{CH}_{3} \mathrm{OO}$ radical, it is observed that the ones with $\mathrm{HO}^{\circ}$ are more feasible and higher exergonic.

3.2.2. Addition reaction at unsaturated bond positions. The addition reactions are set on the possible and less steric hindrance positions of unsaturated bonds. The PES of addition reactions between $\mathrm{CH}_{3} \mathrm{OO}^{\circ}$ radical and falcarinol at $\mathrm{C} 1, \mathrm{C} 4, \mathrm{C} 5$, C6, C7 and C10 side is displayed in Fig. 2. The reactions generally start with the formation of reactants complexes lying 
below reactants of $-2.4,-1.1,-4.7,-2.0,-2.3$ and $-3.3 \mathrm{kcal} \mathrm{mol}^{-1}$ corresponding to addition at the $\mathrm{C} 1, \mathrm{C} 4, \mathrm{C} 5, \mathrm{C} 6$, $\mathrm{C} 7$ and C10 positions. Following this state, the reactions pass transition states (TS), namely TS-C1add, TS-C4add, TS-C5add, TS-C6add, TS-C7add and TS-C10add at the energy barriers of 10.1, 9.6, 15.5, 17.1, 9.6 and $9.3 \mathrm{kcal} \mathrm{mol}^{-1}$, respectively, in which the $\mathrm{C} 1-\mathrm{O}, \mathrm{C} 4-\mathrm{O}, \mathrm{C} 5-\mathrm{O}, \mathrm{C} 6-\mathrm{O}, \mathrm{C} 7-\mathrm{O}$ and $\mathrm{C} 10-\mathrm{O}$ distances are 1.856, 1.918, 1.843, 1.839, 1.915 and $1.899 \AA$, in sequence. The product complexes (PC) are yielded by forming the $\mathrm{C} 1-\mathrm{O}, \mathrm{C} 4-\mathrm{O}$, C5-O, C6-O, C7-O and C10-O bonds of 1.443, 1.386, 1.408, 1.406, 1.387 and $1.455 \AA$, respectively. The relative energies of these states are $0.4,-9.9,4.5,5.0,-8.4$ and $0.5 \mathrm{kcal} \mathrm{mol}^{-1}$, respectively. All addition reactions showing positive $\Delta G$ values are determined to be endergonic (as shown in Table 2). It is clearly observed that the additions at $\mathrm{C} 4$ and $\mathrm{C} 7$ seem to be kinetically and thermodynamically more favorable, in which the reactions involve lower energy barriers than those for other addition reactions. For example, the energy barriers require for the addition at C4 and C7 are 10.7 and $11.9 \mathrm{kcal} \mathrm{mol}^{-1}$ compared to the values of 12.5, 20.2, 19.1 and $12.6 \mathrm{kcal} \mathrm{mol}^{-1}$ corresponding to the addition at C1, C5, C6 and C10, respectively.

Since $\alpha$-vetivone appears as a promising antioxidant via HAT and SET-PT mechanism, attack of $\mathrm{CH}_{3} \mathrm{OO}^{\circ}$ and $\mathrm{HO}^{*}$ radicals on this molecule was similarly investigated. The reactions were performed at easiest $\mathrm{C} 8 \mathrm{-H}$ breaking bond and $\mathrm{C} 9=\mathrm{C} 10$ double bonds (as shown in Fig. 5). IRC plots for all transition states related to reaction of $\mathrm{CH}_{3} \mathrm{OO}^{\circ}$ and $\mathrm{HO}^{\circ}$ radicals with $\alpha$-vetivone are presented in Fig. S3 of ESI. $\dagger$

Before attaining product complex (PC), all reactions firstly pass transition state (TS) with energy of 12.3, 9.3, -3.6 and $-4.7 \mathrm{kcal} \mathrm{mol}^{-1}$ corresponding to TS-addCH 300 , TS-absCH${ }_{3}$ OO, TS-absHO and TS-addHO, in turn (as seen in Fig. 6). The results underline that the $\mathrm{H}$-atom abstractions by both radicals are more prominent than the addition ones. Indeed, $\mathrm{PC}-\mathrm{absCH}_{3} \mathrm{OO}$ and $\mathrm{PC}-\mathrm{absHO}$ are found at -7.8 and -41.9 kcal $\mathrm{mol}^{-1}$ while $\mathrm{PC}$-addCH $\mathrm{CH}_{3} \mathrm{OO}$ and $\mathrm{PC}$-addHO are determined at 0.8 and $-25.3 \mathrm{kcal} \mathrm{mol}^{-1}$, respectively (Fig. 6). As energy of product complex of the reaction with $\mathrm{HO}^{*}$ are much lower than the one with $\mathrm{CH}_{3} \mathrm{OO}^{\circ}$ radical, the scavenging of $\mathrm{HO}^{\circ}$ is indicated to be more favorable. Moreover, the results show that the $\mathrm{H}$-abstraction reaction with $\mathrm{CH}_{3} \mathrm{OO}$ is slightly endergonic with low positive $\Delta G$ value of $1.5 \mathrm{kcal} \mathrm{mol}^{-1}$ (as shown in Table 4), while the addition one is more strongly endergonic with notably positive $\Delta G$ value of $18.0 \mathrm{kcal} \mathrm{mol}^{-1}$. Oppositely, the reactions with $\mathrm{HO}^{*}$ are more exergonic with meaningfully negative $\Delta G$ values of -36.2 and $-14.3 \mathrm{kcal} \mathrm{mol}^{-1}$ corresponding to $\mathrm{H}$-abstraction and addition reactions, respectively (Table 4). This observation follows the same tendency as in the case of falcarinol. Note that the antioxidant molecules preferentially react with reactive $\mathrm{HO}^{*}$ radical.

3.2.3. Natural bond orbital (NBO) analysis. In order to understand the antioxidant mechanism, singly-occupied molecular orbital (SOMO) and atomic spin density (ASP) of the optimized transition states of the $\mathrm{H}$-atom abstraction at $\mathrm{C} 3-\mathrm{H}$ and the addition reactions at different $\pi$-bonds along molecular chain of falcarinol by $\mathrm{CH}_{3} \mathrm{OO}$ radical, as an example, were analyzed (as showed in Fig. 5).

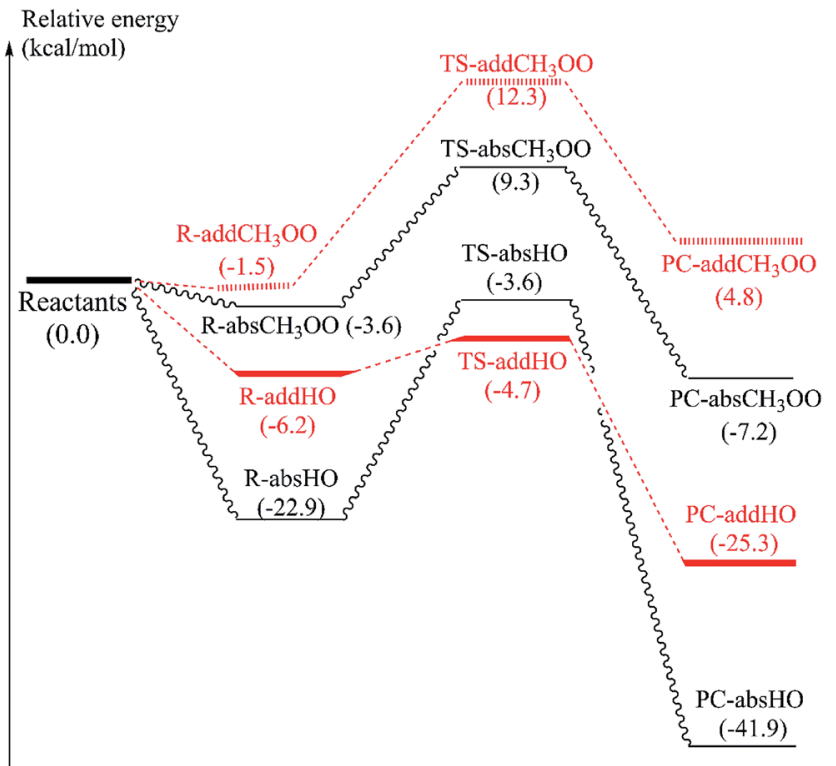

Fig. 6 PES at B3LYP/6-311G(d,p) level of theory of $\mathrm{H}$-atom abstraction reaction at easiest $\mathrm{C} 8-\mathrm{H}$ breaking bond and addition reaction at $\mathrm{C} 9$ positions for $\alpha$-vetivone and $\mathrm{CH}_{3} \mathrm{OO}^{\circ}$ and $\mathrm{HO}^{*}$ radicals.

Concerning $\mathrm{H}$-atom abstraction reaction at $\mathrm{C} 3$, it is widely accepted that there are two mechanisms which generate the same products as HAT: sequential electron proton transfer (SEPT) and proton coupled electron transfer (PCET). They correspond to single electron transfer followed by or occurred simultaneously with proton transfer, respectively. ${ }^{39}$ In order to distinguish which kinds of mechanism falcarinol undergoes, natural bond population (NPA) charge, atomic spin density (ASP) and singly-occupied molecular orbitals (SOMO) analyses are systematically investigated for transition state of HAT reaction (Fig. 7A). As a result, the NPA charge indicates that O1-atom of the $\mathrm{CH}_{3} \mathrm{OO}$ radical carries a negative charge, i.e. $-0.3771 e$, while $\mathrm{H} 3$-atom which split from $\mathrm{C} 3$ atom on falcarinol, shows a positive value of $0.1712 e$. So the $\mathrm{CH}_{3} \mathrm{OO}$ free radical possesses high nucleophile character which favors an attack to the $\mathrm{H} 3-\mathrm{C} 3$ electrophile active sites. As observed on ASP distribution in Fig. 7A, ASP distribution which consists in coefficient of the natural orbital carrying unpaired electron, of the transition state concentrates on two heavy atoms which undergo the $\mathrm{H}$ atom exchange, i.e. $\mathrm{C} 3$ and $\mathrm{O} 1$ atoms. This is corresponding to a HAT process. ${ }^{40}$ Indeed, Mulliken APS analyses show that $\mathrm{O}$ and $\mathrm{C} 3$ atoms carry high positive spin density of 0.4366 and 0.2273 , respectively, while APS of $\mathrm{H}$ atom is slightly negative, i.e. -0.0247 . Furthermore, the SOMO has a significant atomic orbital density oriented along the transition vector, essentially localized on the $\mathrm{C} 3 \cdots \mathrm{H} 3 \cdots \mathrm{O} 1$ vector, with a node plane located at the migrating $\mathrm{H} 3$ transferring atom. The NBO analysis indicates that the third lone pair of electrons on $\mathrm{O} 1$ atom, $\mathrm{LP}(3) \mathrm{O} 1$, is donated to an unoccupied $\sigma^{*}$ antibonding orbital on $\mathrm{C} 3-\mathrm{H} 3, \sigma^{*}(1) \mathrm{C} 3-\mathrm{H} 3$, in the HAT process with stabilization energy equal to $44.2 \mathrm{kcal} \mathrm{mol}^{-1}$ in forming a new $\sigma$ bond $\mathrm{O} 1-\mathrm{H} 3$ on $\mathrm{CH}_{3} \mathrm{OOH}$ (Table 5). 
(A)

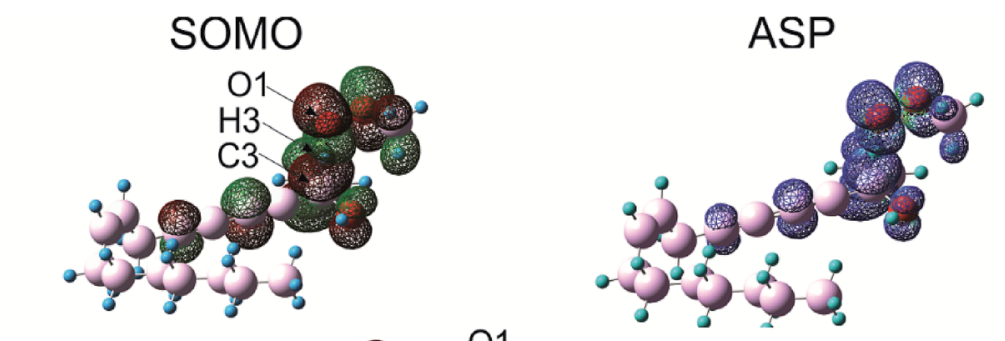

(B)
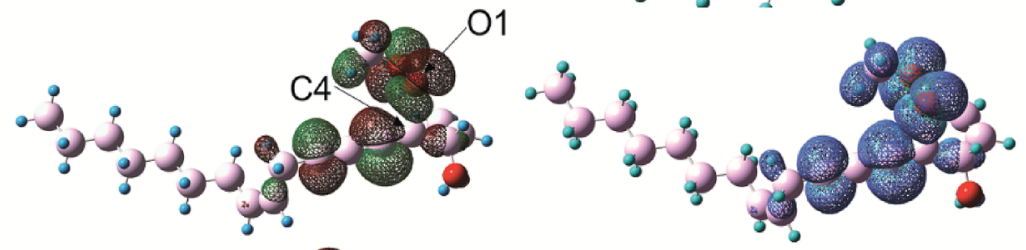

(C)
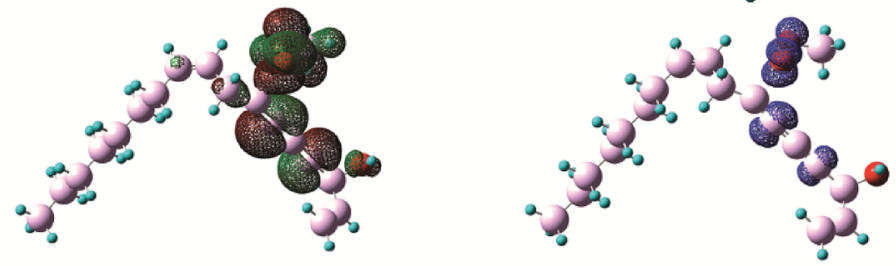

(D)
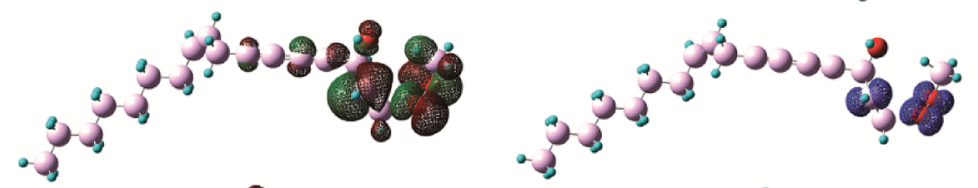

(E)

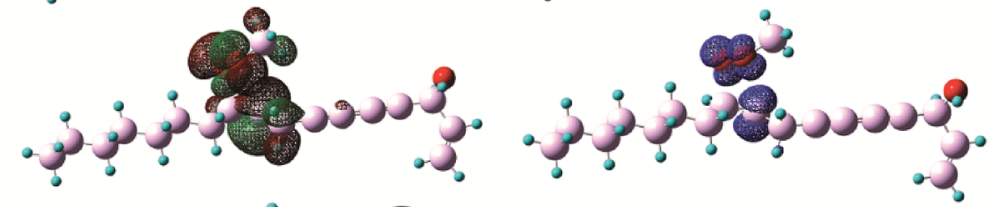

(F)
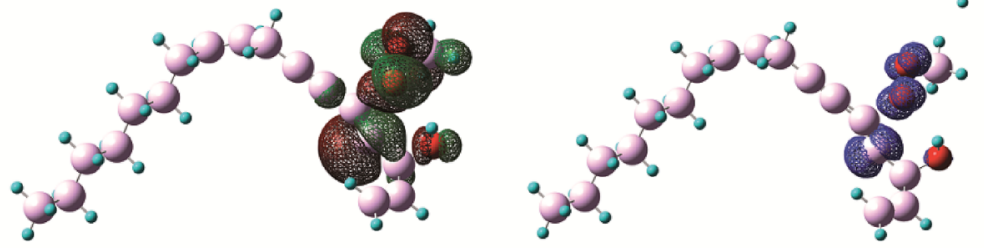

(G)

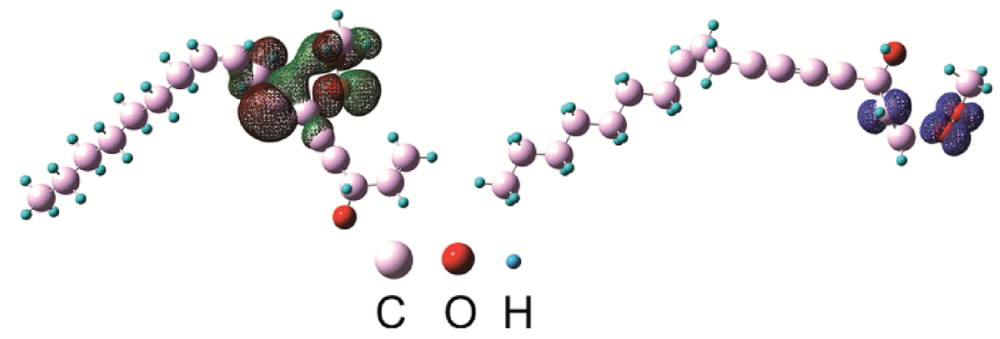

Fig. 7 SOMO densities surface and atomic spin density (ASP) of (A) $\mathrm{H}$-abstraction at C3 and addition reactions at (B) C4; (C) C7; (D) C1; (E) C10; (F) $\mathrm{C} 5$ and $(\mathrm{G}) \mathrm{C} 6$ between $\mathrm{CH}_{3} \mathrm{OO}$ radical and falcarinol. (Orbital density is visualized at isovalue of 0.02 and spin density is mapped from $-5 \times 10^{-4}$ to $5 \times 10^{-4}$ at isovalue of 0.004 ).

For the radical addition reaction to $\mathrm{C} 4 \equiv \mathrm{C} 5$ bond (Fig. $7 \mathrm{~B}$ ), the NPA charge calculation shows that 01-atom of the free radical carries high negative charge, i.e. $-0.3639 e$, in acting as a nucleophile. Meanwhile, the $\mathrm{C} 4$ atom where the free radical attacks, carries small positive charge, i.e. 0.1411e, in showing as an electrophile. The Mulliken spin density distribution shows high spin density concentrated on $\mathrm{O} 1$ atom which has a tendency to approach to C4 carbon atom (Fig. 7B). Meanwhile, the SOMO shows that p orbital on O1-atom has high tendency to overlap with $\pi$-orbital on the $\mathrm{C} 4 \equiv \mathrm{C} 5$ triple bond. The NBO analysis confirms that the third lone pair of electron on $\mathrm{O} 1$ atom, $\mathrm{LP}(3) \mathrm{O} 1$ is transferred to the third unoccupied $\sigma^{*}$ antibonding orbital of the triple bond, $\sigma^{*}(3) \mathrm{C} 4-\mathrm{C} 5$, with stabilization energy equal to $28.9 \mathrm{kcal} \mathrm{mol}^{-1}$. This process tends to form $\sigma$-bond $\mathrm{C} 4-\mathrm{O} 1$, and results in loss of one $\pi$-bond between $\mathrm{C} 4$ and $\mathrm{C} 5$ atoms which changes it to a double bond. The observation for the other addition reactions is quite similar (Fig. 7CG) (Table 5). The electron densities will then be shifted from 
Table 5 Natural bond analysis of transition states of $\mathrm{H}$-atom abstraction reactions and radical addition to $\pi$-bonds reactions ${ }^{a}$

\begin{tabular}{|c|c|c|c|}
\hline & Donor NBO (i) & Acceptor NBO (j) & $\begin{array}{l}E(2), \\
\mathrm{kcal} \mathrm{mol}^{-1}\end{array}$ \\
\hline FALC-C3H $+\mathrm{CH}_{3} \mathrm{OO}^{\bullet}$ & $\mathrm{LP}(3) \mathrm{O} 1$ & $\sigma^{*}(1) \mathrm{C} 1-\mathrm{H} 3$ & 44.2 \\
\hline FALC-C10 $+\mathrm{CH}_{3} \mathrm{OO}^{\circ}$ & $\mathrm{LP}(3) \mathrm{O} 1$ & $\sigma^{*}(2) \mathrm{C} 9-\mathrm{C} 10$ & 34.6 \\
\hline \multirow[t]{4}{*}{ FALC-C7 + $\mathrm{CH}_{3} \mathrm{OO}^{\circ}$} & $\mathrm{LP}(3) \mathrm{O} 1$ & $\sigma^{*}(3) \mathrm{C} 6-\mathrm{C} 7$ & 28.9 \\
\hline & $\pi(3) \mathrm{C} 6-\mathrm{C} 7$ & $\sigma^{*}(2) \mathrm{C} 4-\mathrm{C} 5$ & 16.8 \\
\hline & $\sigma^{*}(2) \mathrm{C} 6-\mathrm{C} 7$ & $\sigma^{*}(3) \mathrm{C} 4-\mathrm{C} 5$ & 58.1 \\
\hline & $\sigma *(3) \mathrm{C} 6-\mathrm{C} 7$ & $\sigma^{*}(2) \mathrm{C} 4-\mathrm{C} 5$ & 56.2 \\
\hline \multirow[t]{3}{*}{ FALC-C6 $+\mathrm{CH}_{3} \mathrm{OO}{ }^{\circ}$} & $\mathrm{LP}(3) \mathrm{O} 1$ & $\sigma^{*}(2) \mathrm{C} 6-\mathrm{C} 7$ & 40.1 \\
\hline & $\sigma^{*}(3) \mathrm{C} 6-\mathrm{C} 7$ & $\sigma^{*}(3) \mathrm{C} 4-\mathrm{C} 5$ & 15.7 \\
\hline & $\sigma *(2) \mathrm{C} 6-\mathrm{C} 7$ & $\sigma^{*}(2) \mathrm{C} 4-\mathrm{C} 5$ & 13.1 \\
\hline FALC-C $5+\mathrm{CH}_{3} \mathrm{OO}{ }^{\circ}$ & $\mathrm{LP}(3) \mathrm{O} 1$ & $\sigma^{*}(2) \mathrm{C} 4-\mathrm{C} 5$ & 38.6 \\
\hline \multirow[t]{4}{*}{ FALC- $\mathrm{C} 4+\mathrm{CH}_{3} \mathrm{OO}^{\circ}$} & $\mathrm{LP}(3) \mathrm{O} 1$ & $\sigma^{*}(3) \mathrm{C} 4-\mathrm{C} 5$ & 28.9 \\
\hline & $\pi(3) \mathrm{C} 4-\mathrm{C} 5$ & $\sigma^{*}(2) \mathrm{C} 6-\mathrm{C} 7$ & 15.7 \\
\hline & $\sigma^{*}(2) \mathrm{C} 4-\mathrm{C} 5$ & $\sigma^{*}(3) \mathrm{C} 6-\mathrm{C} 7$ & 59.5 \\
\hline & $\sigma^{*}(3) \mathrm{C} 4-\mathrm{C} 5$ & $\sigma^{*}(2) \mathrm{C} 6-\mathrm{C} 7$ & 53.8 \\
\hline FALC-C1 $+\mathrm{CH}_{3} \mathrm{OO}{ }^{\circ}$ & $\mathrm{LP}(3) \mathrm{O} 1$ & $\sigma^{*}(2) \mathrm{C} 1-\mathrm{C} 2$ & 39.4 \\
\hline
\end{tabular}

${ }^{a} \pi$ denotes $\pi$ bonding orbital. $\sigma^{*}$ denotes sigma antibonding orbital. LP symbolizes a lone pair of electrons. LP $(n)$ symbolizes the $n^{\text {th }}$ lone pair of electrons.

bonding and antibonding orbitals of $\mathrm{C} 4 \equiv \mathrm{C} 5$ bond like $\pi(3)$ $\mathrm{C} 4 \equiv \mathrm{C} 5, \sigma^{*}(2) \mathrm{C} 4-\mathrm{C} 5$ and $\sigma^{*}(3) \mathrm{C} 4-\mathrm{C} 5$ to the others vacant antibonding orbitals such as $\sigma^{*}(2) \mathrm{C} 6-\mathrm{C} 7, \sigma^{*}(3) \mathrm{C} 6-\mathrm{C} 7$ with the stabilization energy equal to $15.7,59.5$ and $53.8 \mathrm{kcal} \mathrm{mol}^{-1}$, respectively. The observation for the other addition reactions is quite similar (Fig. 7C-G).

\section{Conclusions}

The thermochemical parameters of twenty-one oxygenated monoterpene and desquiterpene compounds extracted from Cleistocalyx operculatus have been studied in detail. Falcarinol is determined as the most effective antioxidant on the basis of both HAT and SPLET mechanisms. In fact, the BDE and PA in the gas phase of falcarinol are $66.5 \mathrm{kcal} \mathrm{mol}^{-1}$ and $341.3 \mathrm{kcal}$ $\mathrm{mol}^{-1}$. The effective property of falcarinol is a result of the presence of both $\mathrm{OH}$ group and unsaturated double/triple bonds in this molecule. Regarding the effect of solvent, it is observed that the hydrogen atom transfer is favorable in nonpolar environment while deprotonation process is supported by polar one where protons show higher solvation enthalpy. Calculated quantum chemical parameters underline that $\alpha$-vetivone represent as the most reactive compounds with the chemical hardness of $4.02 \mathrm{eV}$ and electrophilicity being $2.03 \mathrm{eV}$. This molecule also displays as one of the easiest electron removal with IE value of $8.06 \mathrm{eV}$.

From the potential energy surface (PES) point of view, the interaction between $\mathrm{CH}_{3} \mathrm{OO}^{\circ}$ radical and falcarinol were clarified. The $\mathrm{H}$-abstraction reaction at $\mathrm{C} 3-\mathrm{H}$ position is determined as the most favored with the energy barriers of $-18.7 \mathrm{kcal} \mathrm{mol}^{-1}$. Among the addition reactions, the ones at $\mathrm{C} 4$ position of $\mathrm{C} 4 \equiv \mathrm{C} 5$ and $\mathrm{C} 7$ of $\mathrm{C} 6 \equiv \mathrm{C} 7$ triple bonds are the most favored with the energy barriers of -9.9 and $-8.4 \mathrm{kcal} \mathrm{mol}^{-1}$, respectively. And it is shown that the $\mathrm{H}$-abstraction reaction is exergonic with a negative $\Delta G$ value of $-10.0 \mathrm{kcal} \mathrm{mol}^{-1}$, while all addition reactions are endergonic with positive $\Delta G$ value from 1.7 to $16.6 \mathrm{kcal} \mathrm{mol}^{-1}$.

Interaction between falcarinol and reactive $\mathrm{HO}^{\circ}$ radical was also considered. The PES for $\mathrm{H}$-atom abstraction reaction at the easiest $\mathrm{C} 3-\mathrm{H}$ breaking bond and the addition reaction at $\mathrm{C} 4$ position were investigated. In comparing to the reactions with $\mathrm{CH}_{3} \mathrm{OO}$, it is observed that falcarinol reacts more strongly with $\mathrm{HO}^{\circ}$ radical with significantly lower $\Delta H$ and $\Delta G$ values, i.e. -54.7 and $-47.1 \mathrm{kcal} \mathrm{mol}^{-1}$, respectively for $\mathrm{H}$-abstraction reaction, and -42.9 and $-32.2 \mathrm{kcal} \mathrm{mol}^{-1}$, respectively for addition one.

Singly-occupied molecular orbital (SOMO), natural population atomic (NPA) charge, atomic spin density (ASP) and natural bond orbital (NBO) analysis of the optimized transition states of the reactions between falcarinol and $\mathrm{CH}_{3} \mathrm{OO}{ }^{*}$ radical have been performed, as an example, to clarify the mechanism of these reactions. The mechanism is determined by the transfer of the third lone pair of electrons on O1-atom of $\mathrm{CH}_{3} \mathrm{OO}^{\circ}$ radical to an unoccupied $\sigma^{*}$ antibonding orbital on $\mathrm{C} 3-\mathrm{H} 3$, and on the triple $\mathrm{C} 4 \equiv \mathrm{C} 5, \mathrm{C} 6 \equiv \mathrm{C} 7$ bonds.

In the case of $\alpha$-vetivone, attack of $\mathrm{CH}_{3} \mathrm{OO}^{\circ}$ and $\mathrm{HO}^{*}$ at easiest $\mathrm{C} 8-\mathrm{H}$ breaking bond and at $\mathrm{C} 9=\mathrm{C} 10$ double bonds was similarly studied. The results show that the $\mathrm{H}$-atom abstraction reactions by both radicals are more prominent than the addition ones. Indeed, the energy of product complex for $\mathrm{H}$ abstraction by $\mathrm{CH}_{3} \mathrm{OO}^{\circ}$ and $\mathrm{HO}^{\circ}$ radicals are found -7.2 and $-41.9 \mathrm{kcal} \mathrm{mol}^{-1}$ while the ones of addition reaction are determined at 4.8 and $-25.3 \mathrm{kcal} \mathrm{mol}^{-1}$, respectively. The reactions with $\mathrm{HO}^{\circ}$ are more exergonic than the ones with $\mathrm{CH}_{3} \mathrm{OO}$ radical with meaningfully negative $\Delta G$ values of -36.2 and $-14.3 \mathrm{kcal} \mathrm{mol}^{-1}$ corresponding to $\mathrm{H}$-abstraction and addition reactions, respectively.

According to the results obtained for falcarinol, it could conclude that the antioxidant molecules preferably react with reactive $\mathrm{HO}^{\bullet}$ radical.

\section{Conflicts of interest}

There are no conflicts to declare.

\section{Acknowledgements}

This research is funded by Vietnam National Foundation for Science and Technology Development (NAFOSTED) under grant number 104.06-2015.09.

\section{References}

1 C. Cabrera, R. Gimenez and M. C. Lopez, J. Agric. Food Chem., 2003, 51, 4427-4435.

2 G. Singh, S. Maurya, C. Catalan and M. P. De Lampasona, J. Agric. Food Chem., 2004, 52, 3292-3296.

3 A. I. Hussain, F. Anwar, S. T. Hussain Sherazi and R. Przybylski, Food Chem., 2008, 108, 986-995.

4 K. A. Youdim, S. G. Deans and H. J. Finlayson, J. Essent. Oil Res., 2002, 14, 210-215. 
5 M. Hyldgaard, T. Mygind and R. L. Meyer, Front. Microbiol., 2012, 3, 12.

6 B. Bozin, N. Mimica-Dukic, N. Simin and G. Anackov, J. Agric. Food Chem., 2006, 54, 1822-1828.

7 V. R. Preedy, Essential Oils in Food Preservation, Flavor and Safety, Academic Press, 2015.

8 H. Robert, in Handbook of Essential Oils, CRC Press, 2015, pp. 381-431.

9 L.-B. Maria, in Handbook of Essential Oils, CRC Press, 2015, pp. 619-653.

10 K. H. Baser and B. Gerhard, in Handbook of Essential Oils, CRC Press, 2015, pp. 1-3.

11 M. K. Fasseas, K. C. Mountzouris, P. A. Tarantilis, M. Polissiou and G. Zervas, Food Chem., 2008, 106, 11881194.

12 S. Chatterjee, Z. Niaz, S. Gautam, S. Adhikari, P. S. Variyar and A. Sharma, Food Chem., 2007, 101, 515-523.

13 H.-Y. Chen, Y.-C. Lin and C.-L. Hsieh, Food Chem., 2007, 104, 1418-1424.

14 C. Turek and F. C. Stintzing, Compr. Rev. Food Sci. Food Saf., 2013, 12, 40-53.

15 J. G. Lopez-Reyes, D. Spadaro, A. Prelle, A. Garibaldi and M. L. Gullino, J. Food Prot., 2013, 76, 631-639.

16 R. Lawrence and K. Lawrence, Asian Pac. J. Trop. Biomed., 2011, 1, S51-S54.

17 B. Bozin, N. Mimica-Dukic, N. Simin and G. Anackov, J. Agric. Food Chem., 2006, 54, 1822-1828.

18 N. T. Dung, J. M. Kim and S. C. Kang, Food Chem. Toxicol., 2008, 46, 3632-3639.

19 T. C. Ngo, D. Q. Dao, N. M. Thong and P. C. Nam, RSC Adv., 2016, 6, 30824-30834.

20 S. Purup, E. Larsen and L. P. Christensen, J. Agric. Food Chem., 2009, 57, 8290-8296.

21 J. F. Young, L. P. Christensen, P. K. Theil and N. Oksbjerg, Dose-Response, 2008, 6, 239-251.

22 I.-Y. Choi, J. H. Lim, S. Hwang, J.-C. Lee, G.-S. Cho and W.-K. Kim, Free Radical Res., 2010, 44, 541-551.

23 P. C. Lars, Recent Pat. Food, Nutr. Agric., 2011, 3, 64-77.

24 H.-J. Kim, F. Chen, X. Wang, H. Y. Chung and Z. Jin, J. Agric. Food Chem., 2005, 53, 7691-7695.

25 M. J. Frisch, G. W. Trucks, H. B. Schlegel, G. E. Scuseria, M. A. Robb, J. R. Cheeseman, G. Scalmani, V. Barone, B. Mennucci, G. A. Petersson, H. Nakatsuji, M. Caricato,
X. Li, H. P. Hratchian, A. F. Izmaylov, J. Bloino, G. Zheng, J. L. Sonnenberg, M. Hada, M. Ehara, K. Toyota, R. Fukuda, J. Hasegawa, M. Ishida, T. Nakajima, Y. Honda, O. Kitao, H. Nakai, T. Vreven, J. A. Montgomery Jr, J. E. Peralta, F. Ogliaro, M. Bearpark, J. J. Heyd, E. Brothers, K. N. Kudin, V. N. Staroverov, T. Keith, R. Kobayashi, J. Normand, K. Raghavachari, A. Rendell, J. C. Burant, S. S. Iyengar, J. Tomasi, M. Cossi, N. Rega, J. M. Millam, M. Klene, J. E. Knox, J. B. Cross, V. Bakken, C. Adamo, J. Jaramillo, R. Gomperts, R. E. Stratmann, O. Yazyev, A. J. Austin, R. Cammi, C. Pomelli, J. W. Ochterski, R. L. Martin, K. Morokuma, V. G. Zakrzewski, G. A. Voth, P. Salvador, J. J. Dannenberg, S. Dapprich, A. D. Daniels, O. Farkas, J. B. Foresman, J. V. Ortiz, J. Cioslowski and D. J. Fox, Gaussian 09, Revision E.01, Gaussian, Inc., Wallingford CT, 2013.

26 N. M. Thong, D. T. Quang, N. H. T. Bui, D. Q. Dao and P. C. Nam, Chem. Phys. Lett., 2015, 625, 30-35.

27 J. E. Bartmess, J. Phys. Chem., 1994, 98, 6420-6424.

28 K. K. Irikura, R. D. Johnson and R. N. Kacker, J. Phys. Chem. A, 2005, 109, 8430-8437.

29 E. Cancès, B. Mennucci and J. Tomasi, J. Chem. Phys., 1997, 107, 3032-3041.

30 J. Tomasi, B. Mennucci and E. Cancès, J. Mol. Struct.: THEOCHEM, 1999, 464, 211-226.

31 I. B. Obot, D. D. Macdonald and Z. M. Gasem, Corros. Sci., 2015, 99, 1-30.

32 H. Chermette, J. Comput. Chem., 1999, 20, 129-154.

33 R. P. Iczkowski and J. L. Margrave, J. Am. Chem. Soc., 1961, 83, 3547-3551.

34 R. G. Parr, L. v. Szentpály and S. Liu, J. Am. Chem. Soc., 1999, 121, 1922-1924.

35 G. Wang, Y. Xue, L. An, Y. Zheng, Y. Dou, L. Zhang and Y. Liu, Food Chem., 2015, 171, 89-97.

36 M. Li, W. Liu, C. Peng, Q. Ren, W. Lu and W. Deng, Int. J. Quantum Chem., 2013, 113, 966-974.

37 A. Pérez-González and A. Galano, Int. J. Quantum Chem., 2012, 112, 3441-3448.

38 M. C. Foti, J. Agric. Food Chem., 2015, 63, 8765-8776.

39 S. Olivella, J. M. Anglada, A. Solé and J. M. Bofill, Chem.-Eur. J., 2004, 10, 3404-3410.

40 J. M. Mayer, D. A. Hrovat, J. L. Thomas and W. T. Borden, J. Am. Chem. Soc., 2002, 124, 11142-11147. 